\title{
Modelling global water stress of the recent past: on the relative importance of trends in water demand and climate variability
}

\author{
Y. Wada ${ }^{1}$, L. P. H. van Beek ${ }^{1}$, and M. F. P. Bierkens ${ }^{1,2}$ \\ ${ }^{1}$ Department of Physical Geography, Utrecht University, Heidelberglaan 2, 3584 CS Utrecht, The Netherlands \\ ${ }^{2}$ Unit Soil and Groundwater Systems, Deltares, Princetonlaan 6, 3584 CB Utrecht, The Netherlands
}

Received: 20 July 2011 - Published in Hydrol. Earth Syst. Sci. Discuss.: 1 August 2011

Revised: 30 November 2011 - Accepted: 12 December 2011 - Published: 20 December 2011

\begin{abstract}
During the past decades, human water use has more than doubled, yet available freshwater resources are finite. As a result, water scarcity has been prevalent in various regions of the world. Here, we present the first global assessment of past development of water stress considering not only climate variability but also growing water demand, desalinated water use and non-renewable groundwater abstraction over the period 1960-2001 at a spatial resolution of $0.5^{\circ}$. Agricultural water demand is estimated based on past extents of irrigated areas and livestock densities. We approximate past economic development based on GDP, energy and household consumption and electricity production, which are subsequently used together with population numbers to estimate industrial and domestic water demand. Climate variability is expressed by simulated blue water availability defined by freshwater in rivers, lakes, wetlands and reservoirs by means of the global hydrological model PCRGLOBWB. We thus define blue water stress by comparing blue water availability with corresponding net total blue water demand by means of the commonly used, Water Scarcity Index. The results show a drastic increase in the global population living under water-stressed conditions (i.e. moderate to high water stress) due to growing water demand, primarily for irrigation, which has more than doubled from 1708/818 to $3708 / 1832 \mathrm{~km}^{3} \mathrm{yr}^{-1}$ (gross/net) over the period 1960-2000. We estimate that 800 million people or $27 \%$ of the global population were living under water-stressed conditions for 1960. This number is eventually increased to 2.6 billion or $43 \%$ for 2000 . Our results indicate that increased water demand is a decisive factor for heightened water stress in various regions such as India and North China, enhancing the intensity of water stress up to $200 \%$, while climate variability is often a main determinant of extreme events. However,
\end{abstract}

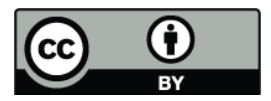

Correspondence to: Y. Wada

(y.wada@uu.nl) our results also suggest that in several emerging and developing economies (e.g. India, Turkey, Romania and Cuba) some of past extreme events were anthropogenically driven due to increased water demand rather than being climate-induced.

\section{Introduction}

Freshwater (i.e. blue water) is a vital resource for various human activities and food production. Yet, the available amount is finite. Large numbers of reservoirs have been constructed to store water, but the increase of impoundment by dams has been tapering off since the 1990s (Chao et al., 2008). At the same time, water needs, primarily for irrigation, have been increasing rapidly since the 1960s. Figure 1 shows past trends of water withdrawal, along with the increase in population, GDP and irrigated areas for the globe and each continent. The global water withdrawal increased at a rate of $17 \%$ per decade between 1960 and 2000 (Vörösmarty et al., 2005), and eventually doubled to $4000 \mathrm{~km}^{3} \mathrm{yr}^{-1}$ in 2000 . For North America and Europe, the increase became smaller after the 1980s, whilst water withdrawal consistently increased for Asia, South America, Africa and Oceania for the period 1960-2000. As a result, water scarcity has become prevalent in many regions of the world (e.g. India, China and the Middle East). The United Nations report that water scarcity is beginning to constrain economic growth in those regions (World Water Assessment Programme, 2009).

To assess global freshwater scarcity (i.e. blue water stress) various studies applied global hydrological models (GHMs) commonly at a spatial resolution of $0.5^{\circ}$ (i.e. $50 \mathrm{~km}$ by $50 \mathrm{~km}$ at the equator). An overview of those studies is shown in Table 1. In several GHMs (e.g. H07 and PCRGLOBWB) reservoir operation schemes have been implemented to better represent altered seasonal river flow when reservoirs are present to store water for drier periods with enhanced demand. Also, the reduction of river discharge by

Published by Copernicus Publications on behalf of the European Geosciences Union. 

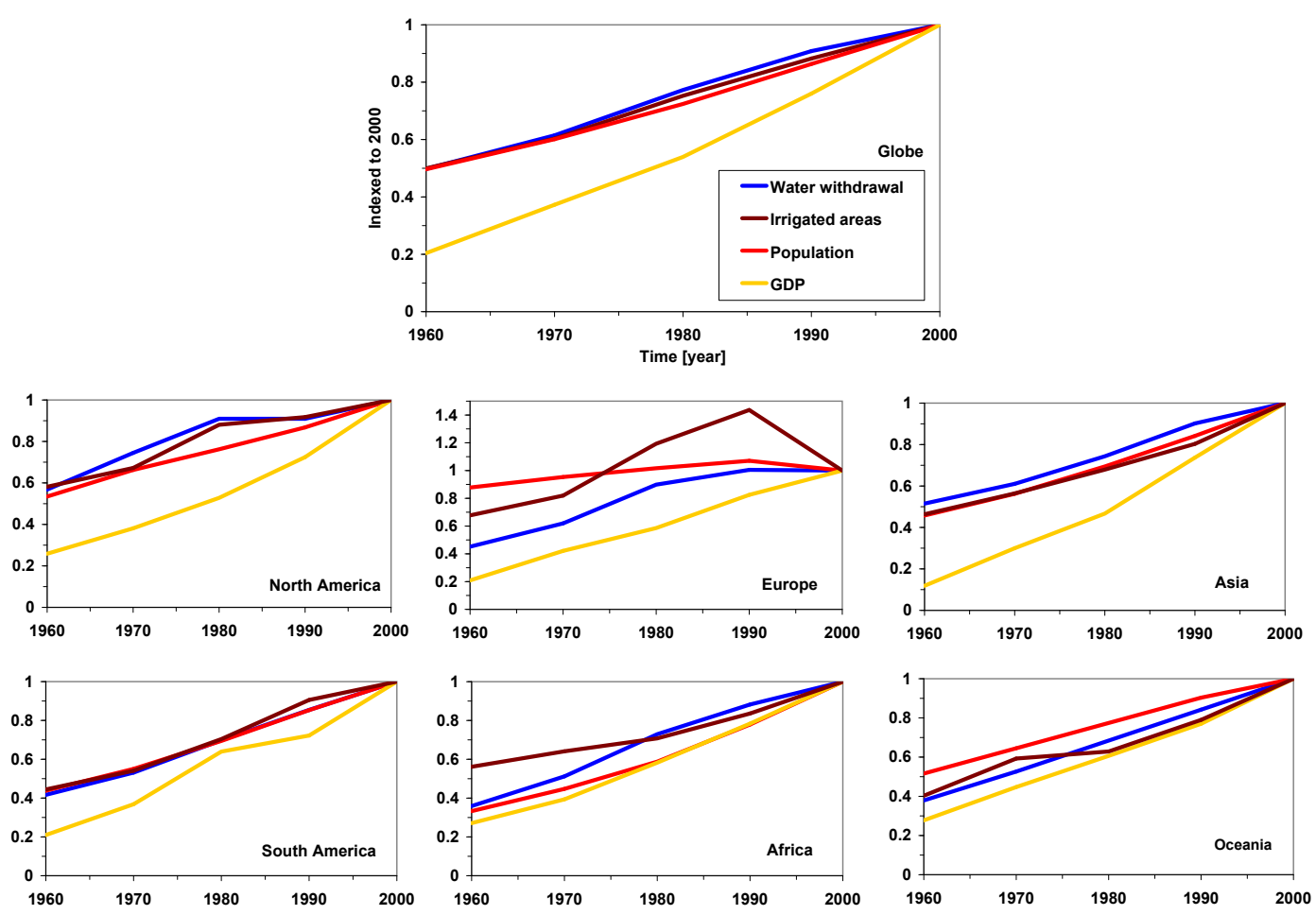

Fig. 1. Past trends of water withdrawal, population, GDP and irrigated areas from 1960 to 2000 for the globe and each continent. They are all indexed to 2000 to characterize their development against water withdrawal. Water withdrawal, population, GDP and irrigated areas were taken from Shiklomanov (2000a,b), World Bank and FAOSTAT, respectively.

upstream human water consumption through river networks has been simulated by using exogenous runoff scheme (cf. Oki et al., 2001; Wada et al., 2011b). In many studies, water scarcity is expressed by the Water Scarcity Index (WSI; see Sect. 2.1) in which simulated freshwater availability is confronted with estimated water demand. As shown in Table 1, the resulting estimates of population under high water stress (i.e. WSI $\geq 0.4$ ) vary considerably. Grid-based estimate results in higher values, as a country-based estimate hides substantial within-country variation of water availability and demand (Arnell, 2004) while sub-annual assessments capture seasonal variations of water stress and thus return higher values than annual assessments (Hanasaki et al., 2008b; Wada et al., 2011b). Despite these differences, most studies indicate high water stress in many (semi-)arid regions such as India, Pakistan, North East China, Central and West USA, North Africa, Iran, Saudi Arabia, South Spain and parts of Australia. In such regions, the demand often exceeds the available surface freshwater resources due to heavy irrigation (UNEP, 1996) which requires large volumes of water in a certain time of the year, when groundwater is additionally used to supplement the deficiency. Only Wada et al. (2011b) have explicitly incorporated groundwater abstraction in their water stress assessment.

The previous assessments, which are listed in Table 1, have identified regions suffering from current water stress and vulnerable to future water stress due to the effects of climate change, yet almost no global studies have assessed the past development of water stress. One exception is a recent study of Kummu et al. (2010). Their results indicated that 1960 is a clear turning point and showed that the global population experiencing high water stress soared from 0.3 to 2.3 billion, i.e. $9 \%$ to $35 \%$ of the global population, over the period 1960-2005, while the figure was less than 0.1 billion before the 1940s. However, they estimated water demand based on population growth only, such that neither past expansion of irrigated areas nor economic growth was considered. Moreover, their coarse spatial and temporal resolution neglected significant spatial and inter- and sub-annual variability of water demand and availability.

To quantify the development of past water stress considering the effects of not only population growth but also economic growth and expanding irrigated areas at a finer temporal and spatial scale, we develop a method to reconstruct past monthly water demand for agricultural, industrial and domestic sectors from 1960 to 2001 at $0.5^{\circ}$, while blue water availability is simulated using the global hydrological model PCR-GLOBWB at the same spatial and temporal resolution. Past water demand is estimated by using the latest available global data sets of socio-economic (e.g. population and GDP), technological (e.g. energy and household consumption and electricity production) and agricultural (e.g. the 
Table 1. Previous model based assessments of global blue water stress.

\begin{tabular}{|c|c|c|c|c|c|c|c|c|}
\hline $\begin{array}{l}\text { Previous stud- } \\
\text { ies }\end{array}$ & $\begin{array}{l}\text { Global hydrologi- } \\
\text { cal model (spatial } \\
\text { resolution) }\end{array}$ & Reservoir/River routing scheme & $\begin{array}{l}\text { Gross/Net water demand } \\
\text { (Livestock, Irrigation, In- } \\
\text { dustry, Domestic) }\end{array}$ & Additional components & $\begin{array}{l}\text { Population under high } \\
\text { water stress (billion; } \\
\% \text { of total) }\end{array}$ & Year & $\begin{array}{l}\text { Spatial reso- } \\
\text { lution }\end{array}$ & $\begin{array}{l}\text { Temporal } \\
\text { resolution }\end{array}$ \\
\hline Arnell (1999) & Macro-PDM $\left(0.5^{\circ}\right)$ & - & Irr., Ind. Dom. (Gross) & $\begin{array}{l}\text { Future scenario (Conven- } \\
\text { tional development sce- } \\
\text { nario) }\end{array}$ & $0.4(8 \%)$ & 1990 & Country & Annual \\
\hline $\begin{array}{l}\text { Vörösmarty } \\
\text { et al. }(2000)\end{array}$ & WBM $\left(0.5^{\circ}\right)$ & $\begin{array}{l}\text { Reservoir routing scheme } \\
\text { (Vörösmarty et al., 1997) }\end{array}$ & Irr., Ind., Dom. (Gross) & $\begin{array}{l}\text { Future scenarios } \\
(\mathrm{Sc} 1, \mathrm{Sc} 2, \mathrm{Sc} 3)\end{array}$ & $1.8(31 \%)$ & 1995 & $0.5^{\circ}$ & Annual \\
\hline $\begin{array}{l}\text { Alcamo et al. } \\
(2000)\end{array}$ & WaterGAP $\left(0.5^{\circ}\right)$ & - & Irr., Ind., Dom. (Gross) & $\begin{array}{l}\text { Future scenarios } \\
\text { (Business-as-usual) }\end{array}$ & $2.1(37 \%)$ & 1995 & Watershed & Annual \\
\hline $\begin{array}{l}\text { Oki et al. } \\
\text { (2001) }\end{array}$ & $\operatorname{TRIP}\left(0.5^{\circ}\right)$ & Exogenous runoff scheme & Irr., Ind., Dom. (Gross) & - & $1.7(30 \%)$ & 1995 & $0.5^{\circ}$ & Annual \\
\hline Arnell (2004) & Macro-PDM $\left(0.5^{\circ}\right)$ & - & Irr., Ind., Dom. (Gross) & $\begin{array}{l}\text { Future scenarios (A1, } \\
\text { A2, B1, B2) }\end{array}$ & $1.4(25 \%)$ & 1995 & Watershed & Annual \\
\hline $\begin{array}{l}\text { Islam et al. } \\
(2007)\end{array}$ & $\operatorname{TRIP}\left(0.5^{\circ}\right)$ & $\begin{array}{l}\text { Exogenous runoff scheme (Oki } \\
\text { et al., 2001) }\end{array}$ & $\begin{array}{l}\text { Unit water requirements to } \\
\text { produce crop and livestock } \\
\text { commodities (Gross) }\end{array}$ & Virtual water flow & $1.2(20 \%)$ & 2000 & $0.5^{\circ}$ & Annual \\
\hline $\begin{array}{l}\text { Alcamo et al. } \\
(2007)\end{array}$ & WaterGAP $\left(0.5^{\circ}\right)$ & $\begin{array}{l}\text { Lake and wetland scheme (Döll } \\
\text { et al., 2003) }\end{array}$ & $\begin{array}{l}\text { Liv., Irr., Ind., } \\
\text { Dom. (Gross) }\end{array}$ & $\begin{array}{l}\text { Future scenarios (A2, } \\
\text { B2) }\end{array}$ & $2.3(40 \%)$ & 1995 & $0.5^{\circ}$ & Annual \\
\hline $\begin{array}{l}\text { Hanasaki et } \\
\text { al. }(2008 \mathrm{a}, \mathrm{b})\end{array}$ & $\mathrm{H} 07\left(1.0^{\circ}\right)$ & $\begin{array}{l}\text { Reservoir routing scheme } \\
\text { (Hanasaki et al., 2006) }\end{array}$ & Irr., Ind., Dom. (Gross) & $\begin{array}{l}\text { Environmental flow re- } \\
\text { quirements }\end{array}$ & $2.4(46 \%)$ & 1995 & $1.0^{\circ}$ & Subannual \\
\hline $\begin{array}{l}\text { Kummu et al. } \\
\text { (2010) }\end{array}$ & STREAM $\left(0.5^{\circ}\right)$ & - & $\begin{array}{l}\text { Per capita water withdrawal } \\
\text { (Gross) }\end{array}$ & $\begin{array}{l}\text { Millennial assesment } \\
\text { (Years: 0-2005) }\end{array}$ & $2.3(35 \%)$ & 2005 & $\begin{array}{l}\text { FPUs (Food } \\
\text { Producing } \\
\text { Units) }\end{array}$ & $\begin{array}{l}\text { Several } \\
\text { decades }\end{array}$ \\
\hline $\begin{array}{l}\text { Wada et al. } \\
\text { (2011) }\end{array}$ & $\begin{array}{l}\text { PCR-GLOBWB } \\
\left(0.5^{\circ}\right)\end{array}$ & $\begin{array}{l}\text { Reservoir routing scheme } \\
\text { (Van Beek et al., 2011) Exoge- } \\
\text { neous runoff scheme }\end{array}$ & Liv., Irr., Ind., Dom. (Net) & $\begin{array}{l}\text { Groundwater abstraction } \\
\text { Desalinated water use }\end{array}$ & $\begin{array}{l}1.1(18 \%)^{\text {annual }} \\
1.7(28 \%)^{\text {subannual }}\end{array}$ & 2000 & $0.5^{\circ}$ & $\begin{array}{l}\text { Annual Sub- } \\
\text { annual }\end{array}$ \\
\hline
\end{tabular}

number of livestock and irrigated areas) drivers. In addition, apart from most of the previous studies, the development of desalinated water use and groundwater abstraction are explicitly considered for the same period since these particular water resources provide additional water availability and subsequently reduce blue water demand.

Throughout the paper we will consistently use the term water demand rather than withdrawal to indicate that we can only estimate potential use, i.e. the water that would be used by a given activity or sector if sufficient water were available (see Fig. 2). Withdrawal is the amount of water that is actually extracted from available water resources including surface freshwater, groundwater and desalination, part of which is consumed or returned. Demand, on the other hand, indicates only potential amount. In many (semi-) arid regions, potential demand can not be satisfied due to limited available water resources and only part of demand that can be met by available water resources is actually withdrawn. In many analyses (e.g. Döll and Siebert, 2002; Wisser et al., 2008; Wada et al., 2011b) one distinguishes gross demand from net demand. The latter is sometimes equated with consumptive water use (e.g. Döll and Siebert, 2002). Net demand is consequently lower than gross demand as water withdrawn for industrial and domestic sectors is recycled and returned to river networks while part of water used for irrigated crops is met by green water (i.e. soil water).

Thus, the main objective of this study is to test the method to reconstruct past water demand and most importantly to quantify the transient effects in past development of blue water stress considering not only climatic variability but also growing water demand over the period 1960-2001. The results pinpoint regions where water stress is intensified by climate variability, e.g. decreased water availability, and/or growing water demand. Such insight is necessary when coping with future potential water scarcity.

\section{Methodology}

\subsection{Definition of blue water stress}

We define water stress by comparing blue water availability with corresponding net total water demand for each grid cell, $i$, at $0.5^{\circ}$. WSI is defined as a means to express how much of the available water is taken up by the demand (Falkenmark, 1989; Falkenmark et al., 1997):

$\mathrm{WSI}_{i}=\frac{\left(D_{T_{\mathrm{Net}} i}-\left(\mathrm{DSW}_{i}+\mathrm{NRGW}_{i}\right)\right)}{\mathrm{SFWA}_{i}}$

where $D_{T_{\text {Net }} i}$ is the net total water demand as a sum of livestock, irrigation, industrial and domestic water demand, DSW and NRGW are the desalinated water use and the nonrenewable groundwater abstraction, i.e. abstraction in excess of recharge, and SFWA is the surface freshwater availability (all in $10^{6} \mathrm{~m}^{3} \mathrm{yr}^{-1}$ ). We use the monthly average of net demand and availability for water stress assessment at monthly time-steps.

It should be noted that this study focuses on blue water stress only. Although we are able to compute non-renewable 


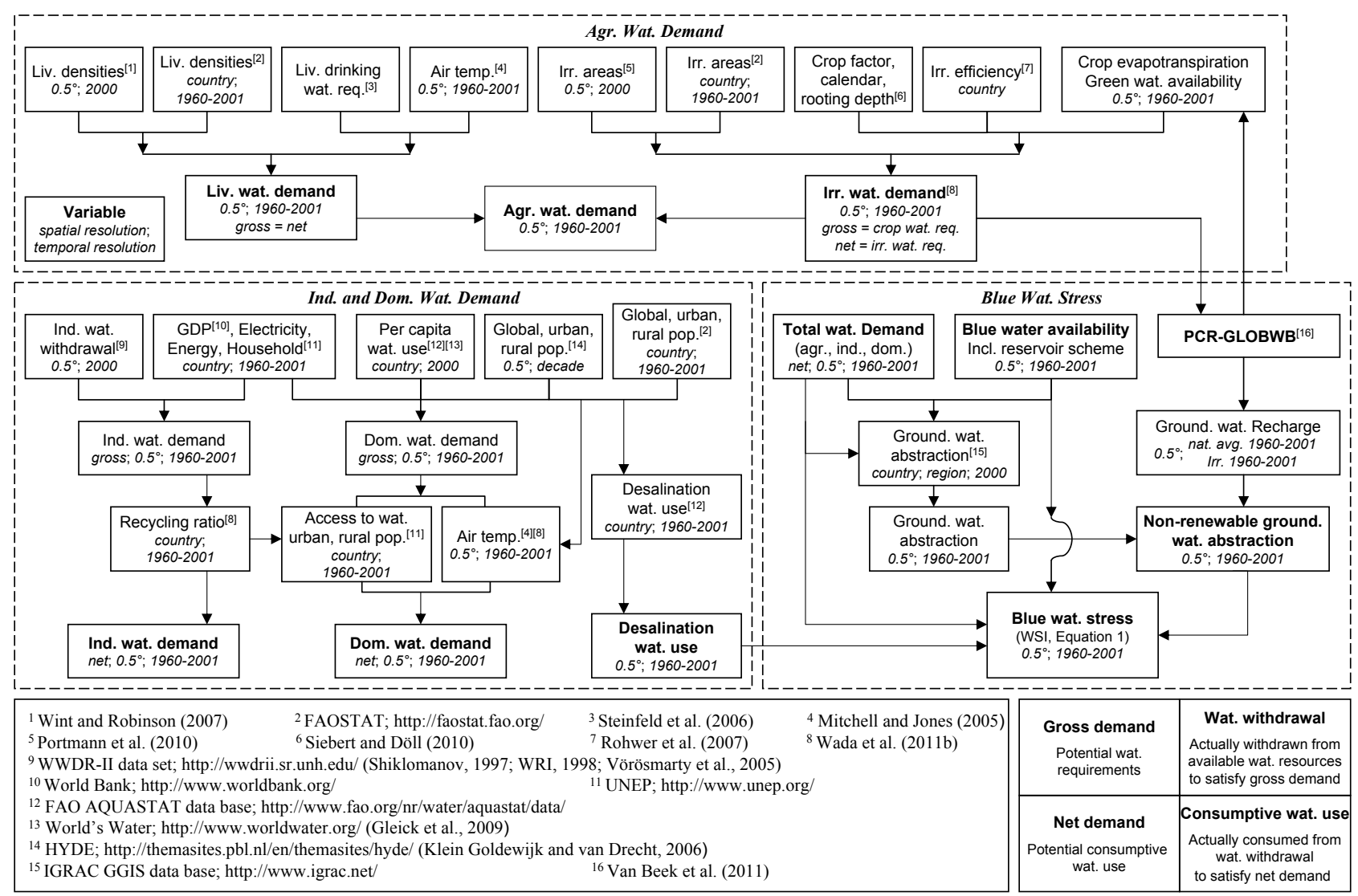

Fig. 2. Flow chart of computation of sectoral water demand and blue water stress with input data sources.

groundwater abstraction rate per grid cell (see Sect. 2.6), absolute amount of available non-renewable groundwater resources is unknown, i.e. data does not exist. We thus subtract the amount of non-renewable groundwater abstraction from net total water demand to compute net total blue water demand. In addition, we also subtract the amount of desalinated water use from net total water demand.

In Eq. (1), water stress occurs whenever the amount of water demand reaches a certain threshold in that of water availability in a same sptio-temporal domain, i.e. grid cell. Moderate water stress occurs between $0.2 \leq$ WSI $<0.4$ while high water stress occurs WSI $\geq 0.4$ (Falkenmark et al., 2007). Although the definitions do not exactly match, these thresholds are often assumed equivalent to per capita water availability of 1700 and $1000 \mathrm{~m}^{3} \mathrm{yr}^{-1}$ and $1000 \mathrm{~m}^{3} \mathrm{yr}^{-1}$ respectively (Kundzewicz et al., 2007).

\subsection{Simulation of blue water stress}

To distinguish the effect of growing water demand from that of climate variability on the development of past water stress, we performed two simulation runs over the period 19602001. First we simulated transient blue water stress in which we used transient net total blue water demand (1960-2001) and blue water availability (1960-2001) (see Eq. 1). Second we simulated blue water stress again but with fixed net total blue water demand for 1960 and transient blue water availability (1960-2001). It should be noted that, for the second simulation, we computed irrigation water demand for the irrigated areas of the year 1960 but with inclusion of long-term climate variability (1960-2001). As a result, irrigation water demand varies over the period 1960-2001 due to changing climate conditions (i.e. precipitation and green water) while industrial and domestic water demand remain constant over the period. This consequently enabled us to quantify the effect of anthropogenic causes (i.e. increase in irrigated areas, population growth and economic development) on blue water stress by comparing the results of the first and second simulation runs. Moreover, we applied a linear regression for both results with a level of significance of $95 \%$ to analyze trends of the first and second simulation runs over the period 1960-2001. The trend of the second simulation enables us to quantify the impact of climate variability on a development of past water stress while the differences in trends between that of the first and second simulation enable us to quantify the effects of growing water demand. We used yearly average and maximum blue water stress for both simulations respectively. Maximum blue water stress was defined by the month with the highest water stress each year. 


\subsection{Reconstruct past water demand over the period 1960-2001}

Data on country-specific water withdrawal is obtainable from the FAO AQUASTAT data base and the WRI (http://www. wri.org/), but it generally has a limited temporal and spatial coverage. Moreover, country statistics on consumptive water use rarely exist. For these reasons, most of previous studies estimate sectoral water demand from various data. Irrigation water, being by far the largest demand among sectors, is estimated by using spatially distributed irrigated areas which are available from several sources commonly at $0.5^{\circ}$ such as Global Map of Irrigated Areas (Döll and Siebert, 2002; Siebert et al., 2005), GIAM (Thenkabail et al., 2006, 2008), Ramankutty et al. (2008) and MIRCA2000 (Portmann et al., 2010). Temporal coverage of these data is, however, limited to the present condition, i.e. around the year 2000. To overcome the lack of available spatially-explicit data, we downscaled the country statistics of the number of livestock, the extent of irrigated areas and population numbers to $0.5^{\circ}$ and used these to reconstruct past water demand over the period 1960-2001. Past economic development was approximated by using GDP, energy and household consumption and electricity production. To compute net demand, we estimated return flow for industrial and domestic sectors by using spatially explicit recycling ratios and accounted green water availability which was simulated by PCR-GLOBWB to partition water used for irrigated crops into blue and green water sources. To capture seasonal variations characterised by high demand and low availability at certain times of the year, water demand and water availability were computed per month.

Figure 2 shows a flow chart that describes how we computed sectoral water demand from various data sources. In the following sections the computation of sectoral water demand is subsequently described in more detail.

\subsubsection{Livestock water demand}

Livestock water demand shares less than $1 \%$ of the global gross water demand and the amount is small in most countries compared to the other sectors. However, livestock water demand is not negligible in some of African countries. For example, in Botswana where people suffer from periodic water scarcity, livestock water demand is larger than irrigation water demand and accounts $23 \%$ of the total water demand (Els and Rowntree, 2003).

We computed livestock water demand by combining livestock densities (i.e. the number of livestock per grid cell) with their drinking water requirements (see Fig. 2). Water demand for irrigated pasture or fodder grasses for feeding livestock is included in irrigation water demand (see Sect. 2.3.2). The gridded global livestock densities include separate maps for cattle, buffalo, sheep, goats, pigs and poultry in 2000 (Wint and Robinson, 2007). We multiplied the number of each livestock in a grid cell by its corresponding drinking water requirements to estimate livestock water demand. We assumed that gross demand for livestock equals net demand; no return flow to the soil or river system occurs. Due to the lack of past gridded livestock densities, we downscaled the country statistics of the numbers of each livestock type for 200 countries (FAOSTAT) to $0.5^{\circ}$ from 1960 to 2001 by using the distribution of the gridded livestock densities of 2000 (see Fig. 2).

The drinking water requirements for livestock are generally higher in summer and lower in winter and are a function of air temperature, for example a sheep requires daily 8.7, 12.9 and 20.11 under $15^{\circ}, 25^{\circ}$ and $35^{\circ}$ air temperature respectively (Steinfeld et al., 2006). We thus determined the drinking water requirements for each livestock type by using spatially and temporally explicit monthly air temperature $\left(0.5^{\circ}\right)$ from 1960 to 2001 (Mitchell and Jones, 2005). The monthly livestock water demand consequently fluctuates over the year while the livestock density of a given year remains constant.

\subsubsection{Irrigation water demand}

Irrigation, being by far the largest demand, comprises $70 \%$ of the global gross water demand (Döll et al., 2009). Various studies computed global irrigation water demand as shown in Table S1 (see Supplement) but their estimates vary depending on the methods and the data used in their calculation. Döll and Siebert (2002), Flörke and Alcamo (2004), Hanasaki et al. (2006) and Sulser et al. (2010) used the CROPWAT method (Smith, 1992) to estimate the global irrigation water demand. They estimated the optimal crop calendar from precipitation and temperature (cf. Döll and Siebert, 2002). Rost et al. (2008) and Hanasaki et al. (2010) also simulated a crop calendar by using LPJmL (Bondeau et al., 2007) and H07 (Hanasaki et al., 2008b) respectively while Siebert and Döll (2010) used a prescribed crop calendar compiled by Portmann et al. (2010).

We opted to use a prescribed crop calendar of Portmann et al. (2010) as done in Siebert and Döll (2010) since uncertainties in simulating a crop calendar are large (Döll and Siebert, 2002). We obtained monthly irrigated areas and crop calendars for 26 crops including irrigated pasture around 2000 from Portmann et al. (2010) and Siebert and Döll (2010). They account for seasonal variability due to various growing seasons of different crops and regional cropping practices under different climatic conditions and distinguish up to nine sub-crops that represent multi-cropping systems in different seasons in different areas per grid cell (see Fig. 2). The corresponding crop development stages, crop factors and crop rooting depth were also obtained from Siebert and Döll (2010). Reference (potential) evapotranspiration was computed by the Penman-Monteith equation according to FAO guidelines (Allen et al., 1998). We then combined gridded irrigated areas with crop factors, growing season lengths and 
reference evapotranspiration to yield monthly crop-specific potential evapotransiration (daily values were aggregated to monthly values) under optimal conditions, i.e. no water stress during irrigation practices, as done in previous studies. Using the same crop calendars, crop factors and irrigated areas as inputs to PCR-GLOBWB and forcing the model with precipitation and reference evapotranspiration data as described in Sect. 2.4, this yielded monthly time series of actual evapotranspiration when no irrigation is applied. The reduction of potential to actual transpiration is calculated based on the total available soil moisture or green water in the soil layers. Over the surface, bare soil evaporation is drawn from the topsoil and no reduction is applicable, except that the potential evaporation rate cannot exceed the saturated hydraulic conductivity of the topsoil for the saturated fraction and for the unsaturated fraction, the rate is restricted by the unsaturated hydraulic conductivity of the topsoil layer (see Sect. 2.2 of Van Beek et al., 2011). These were subsequently used as an estimate of green water use over the irrigated areas. We subtracted this amount from the calculated crop-specific potential evapotranspiration for the irrigated areas to estimate monthly net irrigation water demand. Multiplication with country-specific efficiency factors (Rohwer et al., 2007) to account for losses (i.e. conveyance and application losses) finally yielded monthly gross irrigation water demand. For an extensive description of the methods we refer to Van Beek et al. (2011) and Wada et al. (2011b).

To obtain monthly time series for the past period we repeated this procedure for each year (see Fig. 2), while estimating the growth of irrigated areas by downscaling countryspecific statistics for 230 countries (FAOSTAT) to $0.5^{\circ}$ from 1960 to 2001 by using the distribution of the gridded irrigated areas for 2000 following the method of Wisser et al. (2010).

\subsubsection{Industrial water demand and recycling ratio}

Industrial water demand amounts to $20 \%$ of the global gross water demand and is generally higher in developed countries where the ratio of industrial to total water demand often exceeds $50 \%$.

In general, industrial water demand increases with GDP (Oki and Kanae, 2006). Alcamo et al. (2007) used GDP per capita and electricity production to model future increase of industrial water demand. Later, Shen et al. (2008) revealed a strong linear relationship between relative growths in electricity consumption and industrial GDP and used electricity consumption to model future increase of industrial water demand. We generally followed their approaches but included four variables to better approximate past course of increase in industrial water demand. We thus developed a simple algorithm to compute water use intensities, WUI, for the period 1960-2001.

$\mathrm{WUI}_{\mathrm{cnt}}=\mathrm{EDev}_{\mathrm{cnt}} \times \mathrm{TDev}_{\mathrm{cnt}}$

$$
\begin{aligned}
& \operatorname{EDev}_{\mathrm{cnt}}=\text { Average }\left(\left(\frac{\mathrm{GDP}_{\mathrm{pc}, \text { past }}}{\mathrm{GDP}_{\mathrm{pc}, \text { present }}}\right)^{0.5}\right. \text {, } \\
& \left(\frac{\mathrm{EL}_{\mathrm{pc}, \text { past }}}{\mathrm{EL}_{\mathrm{pc}, \text { present }}}\right)^{0.5},\left(\frac{\mathrm{EN}_{\mathrm{pc}, \text { past }}}{\mathrm{EN}_{\mathrm{pc}, \text { present }}}\right)^{0.5} \text {, } \\
& \left.\left(\frac{\mathrm{HC}_{\mathrm{pc}, \text { past }}}{\mathrm{HC}_{\mathrm{pc}, \text { present }}}\right)^{0.5}\right) \\
& \operatorname{TDev}_{\mathrm{cnt}}=\frac{\left(\frac{\mathrm{EN}_{\mathrm{pc}, \text { past }}}{\mathrm{EL}_{\mathrm{pc}, \text { past }}}\right)}{\left(\frac{E N_{\mathrm{pc}, \text { present }}}{\mathrm{EL}_{\mathrm{pc}, \text { present }}}\right)}
\end{aligned}
$$

where GDP is the gross domestic product, EL is the electricity production and EN and HC are energy and household consumption respectively; pc and cnt denote per capita and per country; present and past indicate year 2000 and years 1960-2001.

EDev approximates an economic development based on four variables, each of which has a strong correlation to the growth of industrial water demand (see Fig. 2). However, EDev does not account for technological development, i.e. industrial restructuring or improved water use efficiency. In general, an increase in industrial water withdrawal considerably slows down after reaching a certain technological advancement. We then used energy consumption per unit electricity production to approximate technological development, TDev. TDev converges as energy consumption intensity reaches a saturation amount. Finally, the computed WUI was multiplied with the industrial water demand for 2000 (Shiklomanov, 1997; World Resources Institute, 1998; Vörösmarty et al., 2005) to estimate the gross demand from 1960 to 2001 (see Fig. 2).

Significant amounts of water withdrawn for industrial purposes return to the river system after use due to water recycling technology particularly in developed countries where $80 \%$ of water used in the industrial sectors is currently recycled in Japan (Oki and Kanae, 2006; Ministry of Land, Infrastructure, and Transport in Japan, 2007). As a result, only part of water withdrawn for industry is actually consumed or lost i.e. yielding a net demand. Since the data on country recycling ratios rarely exist, we applied the method of Wada et al. (2011b) who interpolated country recycling ratios on the basis of the historical development of the recycling ratios and GDP per capita of Japan which resulted in three averaged values of $80 \%, 65 \%$ and $40 \%$ for developed (i.e. high income), emerging (i.e. middle income) and developing (i.e. low income) economies respectively. If a country reached the developed economy as a result of GDP growth, the ratio was kept as $80 \%$ throughout the period.

Gross industrial water demand was then combined with the interpolated recycling ratios to arrive as net demand. If there was no GDP data (e.g. Western Sahara), we applied the minimum $40 \%$ as it is reasonable to assume that water recycling is present along with industrial facilities. The monthly 
net industrial water demand was kept constant over the year similar to the study of Hanasaki et al. (2006) and Wada et al. (2011b).

\subsubsection{Domestic water demand}

The domestic sector accounts for $10 \%$ of the global gross water demand. Domestic water demand has increased rapidly due to population growth, particularly in emerging and developing countries such as China, India, Pakistan, Bangladesh and Mexico.

We estimated gross domestic water demand by multiplying the number of persons in a grid cell with the countryspecific per capita domestic water withdrawal from 1960 to 2001 (see Fig. 2). The past country-specific per capita domestic water withdrawals were estimated by multiplying the country-specific per capita domestic water withdrawal in 2000, which were taken from the FAO AQUASTAT data base

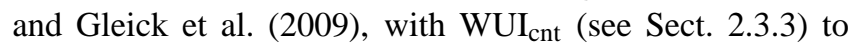
account for past economic and technological development. As gridded maps of the global population are only available for each decade (Klein Goldewijk and van Drecht, 2006), we combined these with yearly country population data (FAOSTAT) to estimate gridded population maps for each year. For instance, we downscaled the country population statistics from 1966 to 197 to $0.5^{\circ}$ according to the distribution of the gridded global population map of 1970 .

Similar to the industrial sector, large parts of water withdrawn for the domestic sector return to the river network. The amount depends on technological development and the number of households which are connected to water supply and sewer facilities. To estimate this return flow (which subsequently enables us to quantify net demand), we used the interpolated recycling ratios (see Sect. 2.3.3) and data on access to water for urban and rural population obtained from the UNEP. Here, gridded time series of the global urban and rural population were computed with the same method as done for global population (see Fig. 2). Net domestic water demand was then calculated as follows:

$$
\begin{aligned}
& D_{\text {Dom }_{\text {Net } i}}=D_{\text {Dom }_{\text {Gross } i}} \times\left(1.0-\left(\mathrm{AW}_{i} \times \mathrm{RR}_{\mathrm{cnt}}\right)\right) \\
& \mathrm{AW}_{i}=\left(\mathrm{FP}_{\text {Urban }, i} \times \mathrm{AW}_{\text {Urban, }, \mathrm{cnt}}\right)+\left(\mathrm{FP}_{\text {Rural }, i} \times \mathrm{AW}_{\text {Rural }, \text { cnt }}\right)
\end{aligned}
$$

where $D_{\text {Dom }}$ is the domestic water demand $\left[10^{6} \mathrm{~m}^{3}\right]$. AW is the fractional distribution of population which have access to water, $\mathrm{RR}$ is the recycling ratio and FP is the gridded fraction over total population [dimensionless]. Net, Gross, Urban and Rural denote net and gross demand, and urban and rural population, respectively.

To consider seasonal variability of domestic water demand which is generally higher in summer and lower in winter, we used air temperature (Mitchell and Jones, 2005) as a proxy to compute monthly fluctuations of net domestic water demand. We refer to Wada et al. (2011b) for a detailed description of this method.

\subsection{Simulate blue water availability}

We simulated available freshwater in rivers, lakes, wetlands and reservoirs by using the global hydrological model PCRGLOBWB (PCRaster GLOBal Water Balance; Van Beek and Bierkens, 2009; Van Beek et al., 2011). PCR-GLOBWB is a conceptual, process-based water balance model of the terrestrial part of the hydrological cycle except Antarctica, and is in line with existing GHMs such as WBM (Vörösmarty et al., 2000), WaterGAP (Alcamo et al., 2000), WGHM (Döll et al., 2003) and WASMOD-M (Widén-Nilsson et al., 2007). It simulates for each grid cell $\left(0.5^{\circ} \times 0.5^{\circ}\right.$ globally $)$ and for each time step (daily) the water storage in two vertically stacked soil layers and an underlying groundwater layer, as well as the water exchange between the layers and between the top layer and the atmosphere (rainfall, evaporation and snow melt). The model also calculates canopy interception and snow storage. Sub-grid variability is taken into account by considering separately tall and short vegetation, open water (i.e. lakes, reservoirs, floodplains and wetlands), different soil types (FAO Digital Soil Map of the World), and the area fraction of saturated soil calculated by Improved ARNO scheme (Hagemann and Gates, 2003) as well as the frequency distribution of groundwater depth based on the surface elevations of the $1 \times 1 \mathrm{~km}$ Hydrolk data set. Fluxes between the lower soil reservoir and the groundwater reservoir are mostly downward, except for areas with shallow groundwater tables, where fluxes from the groundwater reservoir to the soil reservoirs are possible (i.e. capillary rise) during periods of low soil moisture content (Yeh and Famiglietti, 2009). The total specific runoff of a cell consists of saturation excess surface or direct runoff, melt water that does not infiltrate, runoff from the second soil reservoir (interflow) and groundwater runoff (baseflow) from the lowest reservoir.

PCR-GLOBWB was forced with daily fields of precipitation, reference evapotranspiration and temperature over the period 1958 to 2001. Precipitation and air temperature were prescribed by the CRU TS 2.1 monthly dataset (Mitchell and Jones, 2005; New et al., 2000) which was subsequently downscaled to daily fields by using the ERA40 re-analysis data (Uppala et al., 2005). Although the CRU TS 2.1 underestimates precipitation due to snow undercatch (Fiedler and Döll, 2007) over the Arctic regions, this weakness is of little consequence for this study as water stress rarely exists in such areas. Prescribed reference evapotranspiration was calculated based on the Penman-Monteith equation (Allen et al., 1998) by using time series data of CRU TS 2.1 with additional inputs of radiation and wind speed from the CRU CLIM 1.0 climatology data (New et al., 2002).

Simulated specific runoff from the two soil layers (i.e. direct runoff and interflow) and the underlying groundwater layer (i.e. base flow) was routed along the drainage network based on DDM30 (Döll and Lehner, 2002) by using the kinematic wave approximation of the Saint-Venant equation (Chow et al., 1988). The effect of open water evaporation, 
storage changes by lakes and attenuation by floodplains and wetlands were taken into account. A newly developed reservoir operation scheme was also implemented, which is dynamically linked with the routing module (Van Beek et al., 2011). This reservoir scheme works with the target storage over a defined period (e.g. a month) ensuring its proper functioning given the forecasts of inflow and downstream demand along the drainage network. The target storage determines outflow from reservoirs and is updated when actual inflow and demand differ from the previously forecasted values based on past average values. Four reservoir operations being water supply, flood control, hydropower generation and navigation are distinguished (cf. Haddeland et al., 2006) while reservoir data is obtained from the GLWD dataset (Lehner and Döll, 2004). The effect of upstream water consumption was incorporated by an exogenous runoff scheme which simulates the reduction of river discharge by subtracting net total water demand through the drainage network (Wada et al., 2011b).

\subsection{Desalinated water use}

Desalinated water use is generally limited to coastal areas but provides additional water availability. Around the globe, more than 10000 desalination plants in 120 countries are in operation (World Water Assessment Programme, 2003). We temporally downscaled country statistics of desalinated water use from the FAO AQUASTAT data base, which are reported at 5-year intervals, to yearly statistics based on country population growth for the period 1960-2001 (see Fig. 2). We then spatially downscaled the country values onto a global coastal ribbon of around $40 \mathrm{~km}$ based on gridded population intensities (see Sect. 2.3.4). This is based on the fact that desalinated water is mostly used in coastal areas. Monthly desalinated water use is kept at constant over the year.

\subsection{Estimate non-renewable groundwater abstraction}

The amount of groundwater that is abstracted in excess of groundwater recharge will, albeit temporally and nonrenewably, decrease the demand for blue water, which subsequently mitigates blue water stress. For the period 1960 to 2001, we estimated the amount of non-renewable groundwater abstraction by subtracting simulated groundwater recharge from gridded groundwater abstraction. Compared to Wada et al. $(2010,2011 \mathrm{~b})$ we followed an improved approach when downscaling country-based data on groundwater abstraction to grid-based estimates, while additionally accounting for recharge that occurs from irrigation. These methods are described in the following sections in more detail.

\subsubsection{Natural and artificial groundwater recharge}

The natural groundwater recharge equals to net flux from the lowest soil layer to the groundwater layer, i.e. deep percolation minus capillary rise in PCR-GLOBWB (Wada et al., 2010). To account return flow from irrigation, $R_{\mathrm{Irr}}$, to the groundwater layer, we simulated additional recharge by the following approximation (Wada et al., 2011a):

$R_{\mathrm{Irr}, i}=\operatorname{Min} .\left(L_{\mathrm{Irr}, i}, k\left(\theta_{\mathrm{E} \_\mathrm{FC}, i}\right) \times A_{\mathrm{Irr}, i}\right)$

where $L_{\text {Irr }}$ is the amount of irrigation losses as estimated from the country-specific efficiency factors $\left[\mathrm{m}^{3} \mathrm{day}^{-1}\right]$, $k\left(\theta_{\mathrm{E}_{-} \mathrm{FC}}\right)$ is the unsaturated hydraulic conductivity at field capacity [m day ${ }^{-1}$ ] and $A_{\text {Irr }}$ is the corresponding irrigated area $\left[\mathrm{m}^{2}\right]$.

This formulation is based on the fact that in irrigation practice water is supplied to wet the soil to field capacity during the application and the amount of irrigation water in excess of field capacity can percolate to the groundwater system. The additional recharge rate thus equals the unsaturated hydraulic conductivity of the bottom soil layer at field capacity, assuming gravity drainage. However, the total percolation losses were further constrained by the reported countryspecific loss factors (Rohwer et al., 2007). From this, we estimated globally the return flow during irrigation application from 1960 to 2001.

\subsubsection{Groundwater abstraction}

Groundwater abstraction is highly uncertain due to scarce observational data and has been rarely incorporated in global hydrological modelling. Since the exact locations where groundwater is abstracted are not known, Wada et al. (2010) used the IGRAC GGIS data base and downscaled country groundwater abstraction data to 0.5 by using net total water demand as a proxy. However, this method overestimates abstraction rates in areas where demand is largely met by surface freshwater. Here, we downscaled the country value to 0.5 by taking deficits of surface freshwater availability over corresponding net total water demand (see Fig. 2).

First, for each month, $m$, from the year 2000 and for each grid cell, $i$, we calculated deficits, Defs ${ }_{m, i}$, between the surface water availability, $\mathrm{SFWA}_{m, i}$, as simulated by PCR-GLOBWB and the computed net total water demand, $D_{T_{\mathrm{Ne} t m, i}}$. Because we are interested in groundwater as an alternative source, we limited our analysis to regions where aquifers are present (major groundwater regions of the world according to the IGRAC GGIS). We subsequently estimated annual deficits, $\operatorname{Defs}_{\mathrm{a}, i}$, for 2000 as:

$\operatorname{Defs}_{\mathrm{a}, i}=\sum_{m=1}^{12} \operatorname{Defs}_{m, i}=\sum_{m=1}^{12}\left(D_{T_{\mathrm{Net}} m, i}-\mathrm{SFWA}_{m, i}\right)$.

We thus assumed that grid cells with deficits are the main locations where groundwater is abstracted as an alternative resource to satisfy the demand. 
Table 2. Estimated livestock water demand from 1960 to 2000. For comparison, the estimates of Steinfeld et al. (2006) are given for 2000.

\begin{tabular}{lllllllll}
\hline Year & $\mathrm{km}^{3} \mathrm{yr}^{-1}$ & Cattle & Buffaloes & Sheep & Goats & Pigs & Poultry & Total \\
\hline 1960 & This study & 8.05 & 0.85 & 1.13 & 0.24 & 0.15 & 0.19 & 10.61 \\
& & $(75.9 \%)$ & $(8.0 \%)$ & $(10.6 \%)$ & $(2.3 \%)$ & $(1.4 \%)$ & $(1.8 \%)$ & $(100.0 \%)$ \\
\hline \multirow{2}{*}{1970} & This study & 9.06 & 0.96 & 1.28 & 0.31 & 0.26 & 0.24 & 12.11 \\
& & $(74.8 \%)$ & $(7.9 \%)$ & $(10.6 \%)$ & $(2.6 \%)$ & $(2.1 \%)$ & $(2.0 \%)$ & $(100.0 \%)$ \\
\hline \multirow{2}{*}{1980} & This study & 10.25 & 1.14 & 1.29 & 0.42 & 0.47 & 0.33 & 13.90 \\
& & $(73.7 \%)$ & $(8.2 \%)$ & $(9.3 \%)$ & $(3.0 \%)$ & $(3.4 \%)$ & $(2.4 \%)$ & $(100.0 \%)$ \\
\hline \multirow{2}{*}{1990} & This study & 11.23 & 1.39 & 1.46 & 0.53 & 0.51 & 0.59 & 15.71 \\
& & $(71.5 \%)$ & $(8.8 \%)$ & $(9.3 \%)$ & $(3.4 \%)$ & $(3.2 \%)$ & $(3.8 \%)$ & $(100.0 \%)$ \\
\hline \multirow{2}{*}{2000} & This study & 10.86 & 1.63 & 1.21 & 0.71 & 0.61 & 0.92 & 15.94 \\
& & $(68.1 \%)$ & $(10.2 \%)$ & $(7.6 \%)$ & $(4.5 \%)$ & $(3.8 \%)$ & $(5.8 \%)$ & $(100.0 \%)$ \\
& Steinfeld et al. & 11.40 & 1.36 & 1.11 & 0.77 & 0.69 & 0.93 & 16.26 \\
& $(2006)$ & $(70.1 \%)$ & $(8.4 \%)$ & $(6.8 \%)$ & $(4.8 \%)$ & $(4.2 \%)$ & $(5.7 \%)$ & $(100.0 \%)$ \\
\hline
\end{tabular}

Second, the annual deficits, Defs $\mathrm{a}_{\mathrm{a}, i}$, were filled by the amount of available country-based groundwater abstraction until total water demand was satisfied by groundwater abstraction per grid cell. Total annual deficits per country, Defs $_{\mathrm{a}}$, are given by:

$\operatorname{Defs}_{\mathrm{a}}=\sum_{i=1}^{n} \operatorname{Defs}_{\mathrm{a}, i}$

where $n$ is the number of grid cells with deficits per country.

If the total annual deficits were larger than the available annual groundwater abstraction in a country, Defs $_{\mathrm{a}}>$ Ground $_{\text {Wa }}$, (e.g. Egypt, Sudan, Mali, Niger, Sudan, Turkmenistan and Uzbekistan), we distributed the country abstraction according to the intensities rather than the volume of the deficits. In many cases the available abstraction is larger than the total deficits in a country and the remaining country-based abstraction $\left(\right.$ Ground $_{\mathrm{Wa}}-$ Defs $_{\mathrm{a}}$ ) was further allocated relative to the intensity of the net total water demand over its country total (again limited to cells in major groundwater regions):

Ground $_{\mathrm{Wa}, i}=\operatorname{Defs}_{\mathrm{a}}+\left(\right.$ Ground $\left._{\mathrm{Wa}}-\operatorname{Defs}_{\mathrm{a}}\right) \times \frac{D_{T_{\mathrm{Net}} \mathrm{a}, i}}{\sum_{i=1}^{n} D_{T_{\mathrm{Net}} \mathrm{a}, i}}$.

We assessed the past trend of groundwater abstraction at firstorder by assuming that country-based groundwater abstraction increases linearly with water demand. So for a given year, $k$, an estimate of country-based groundwater abstraction was obtained by multiplying the groundwater abstraction of 2000 by the ratio of country-based water demand of year, $k$, over that of 2000 water demand:

Ground $_{\mathrm{Wa}, \mathrm{cnt}, k}=$ Ground $_{\mathrm{Wa}, \mathrm{cnt}, 2000} \times \frac{D_{T_{\mathrm{Net}} \mathrm{a}, \mathrm{cnt}, k}}{D_{T_{\mathrm{Net}} \mathrm{a}, \mathrm{cnt}, 2000}}$.
Next, by repeating for each year the methodology previously described, we thus computed gridded groundwater abstraction over the period 1960-2001.

\section{Results}

\subsection{Accuracy of reconstructed water demand}

We subsequently tested the reliability of our estimated water demand. The gross sectoral and total water demand per country were compared to reported values which were taken from the FAO AQUASTAT data base. Table S4 (see Supplement) lists $R^{2}$ (the coefficient of determination) and $\alpha$ (slope of regression line), which were derived from the comparisons between original values, while Figs. 3 and 6 show the comparisons in log-log plots. Furthermore, the gross and net total water demand were compared with estimated values for 80 countries which were taken from Shiklomanov (2000a,b).

\subsubsection{Sectoral water demand}

Table 2 shows the estimated livestock water demand from 1960 to 2000. Total livestock water demand increased more than $50 \%$ from 10.61 to $16.26 \mathrm{~km}^{3} \mathrm{yr}^{-1}$ over the period. Cattle accounts for $70 \%$ of all the livestock water demand. Buffaloes and sheep account for only $10 \%$, while goats, pigs and poultry share less than $5 \%$ of the livestock water demand. Our estimates are slightly lower but agree well with those of Steinfeld et al. (2006) for 2000. For irrigation, our estimated gross/net irrigation water demand globally increased more than two-fold from $1268 / 645$ to $2628 / 1376 \mathrm{~km}^{3} \mathrm{yr}^{-1}$ over the period 1960-2000. Our estimates are comparable to the other estimates and the reported values from the FAO AQUASTAT data base (see Table 3 and Table S1 in the Supplement). 

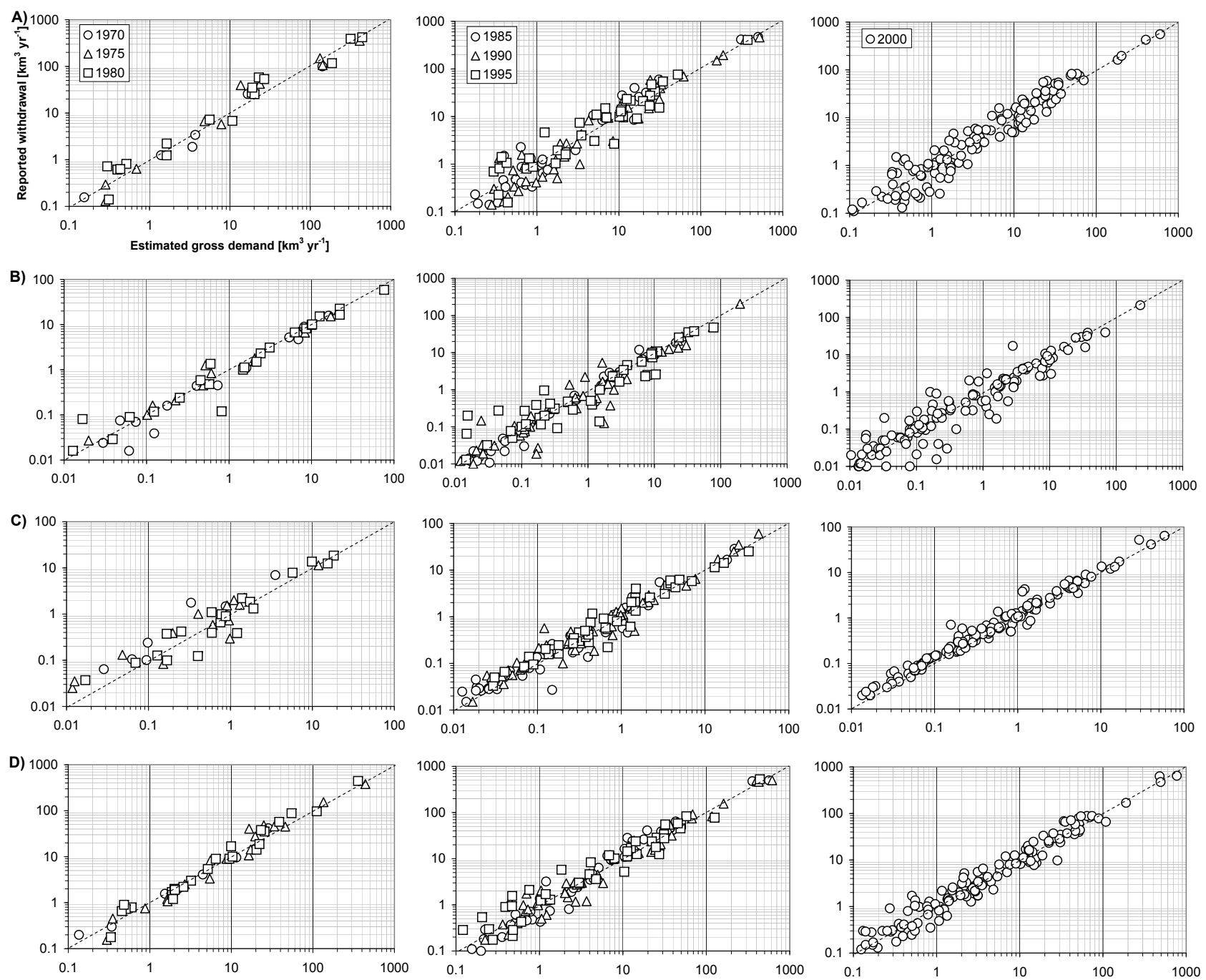

Fig. 3. Comparison between estimated gross water demand (x-coordinate) and reported water withdrawal (y-coordinate) for (a) agricultural, (b) industrial, (c) domestic sector and (d) total per country from 1970 to 2000 in log-log plots. The reported water withdrawals were taken from the FAO AQUASTAT data base. The dashed lines represent the 1:1 line.

It should, however, be noted that the FAO AQUASTAT data base contains many missing values before 1990 inclusive. We compared per country the estimated gross agricultural water demand with the reported value taken from the FAO AQUASTAT data base (see Fig. 3a). Good agreements were obtained from 1970 to 2000 for most countries including major agricultural water users such as India, China, USA, Pakistan and Mexico. But deviations are relatively large for Iraq, Finland, Austria, Central African Republic and Trinidad and Tobago. The reported values of the FAO AQUASTAT data base are not available before 1970. Overall, $R^{2}$ and $\alpha$ range from 0.96 to 0.99 and from 0.88 to 1.10 respectively (see Table S4 in the Supplement).

Our estimated global gross/net industrial water demand doubled from $356 / 116$ to $752 / 257 \mathrm{~km}^{3} \mathrm{yr}^{-1}$ over the period 1960-2000 (Table 3). Comparisons of estimated gross industrial water demand per country with the reported values show good correlations (Fig. 3b). $R^{2}$ is over 0.97 except for 1995 (Table S4 in the Supplement) and $\alpha$ ranges from 0.80 to 0.99. Deviations are large for Argentina, Ethiopia, Greece, Indonesia, Lebanon, Nicaragua, Panama, Puerto Rico and Turkmenistan where we generally overestimate the demand. Nevertheless, overall we have good agreements for most of countries including major industrial water users such as USA, China, Germany, Canada and India.

Estimated gross/net domestic water demand nearly quadrupled from $85 / 57$ to $328 / 198 \mathrm{~km}^{3} \mathrm{yr}^{-1}$ over the period 1960-2000. Our estimates are comparable to those of other studies which are listed in Table 3. Comparison with the reported value per country also shows a good agreement from 1970 to 2000 with $R^{2}$ being over 0.95 (Fig. 3c; Table S4 in the Supplement). $\alpha$ ranges from 0.90 to 1.15 . Although the 
Table 3. Estimated sectoral and total water demand compared with reported values from the FAO AQUASTAT data base and other estimates from 1960 to 2000 .

\begin{tabular}{|c|c|c|c|c|c|c|}
\hline $\mathrm{km}^{3} \mathrm{yr}^{-1}$ & Gross/Net demand & 1960 & 1970 & 1980 & 1990 & 2000 \\
\hline \multicolumn{7}{|c|}{ Agriculture (Irrigation) } \\
\hline FAO AQUASTAT & Withdrawal & - & - & 1463 & 1996 & 2659 \\
\hline Shen et al. (2008) & Gross & - & - & 1857 & 2271 & 2658 \\
\hline Shiklomanov $(2000 \mathrm{a}, \mathrm{b})$ & Withdrawal/Consumption & $1481 / 1005$ & $1743 / 1186$ & $2112 / 1445$ & $2425 / 1691$ & $2605 / 1834$ \\
\hline This study & Gross/Net & $1268 / 645$ & $1519 / 756$ & $1900 / 958$ & $2258 / 1089$ & $2628 / 1376$ \\
\hline \multicolumn{7}{|c|}{ Industry } \\
\hline FAO AQUASTAT & Withdrawal & - & - & 499 & 629 & 777 \\
\hline Shen et al. (2008) & Gross & - & - & 543 & 642 & 777 \\
\hline Shiklomanov $(2000 \mathrm{a}, \mathrm{b})$ & Withdrawal/Consumption & $339 / 31$ & $547 / 51$ & $713 / 71$ & $735 / 79$ & $776 / 88$ \\
\hline This study & Gross/Net & $356 / 116$ & $452 / 143$ & $607 / 191$ & $692 / 210$ & $752 / 257$ \\
\hline \multicolumn{7}{|c|}{ Domestic } \\
\hline FAO AQUASTAT & Withdrawal & - & - & 189 & 260 & 377 \\
\hline Shen et al. (2008) & Gross & - & - & 217 & 275 & 390 \\
\hline Shiklomanov (2000a,b) & Withdrawal/Consumption & $118 / 21$ & $160 / 29$ & $219 / 38$ & $305 / 45$ & $384 / 50$ \\
\hline This study & Gross/Net & $85 / 57$ & $119 / 77$ & $201 / 126$ & $262 / 157$ & $328 / 198$ \\
\hline \multicolumn{7}{|c|}{ Total } \\
\hline FAO AQUASTAT & Withdrawal & - & - & 2151 & 2885 & 3812 \\
\hline Shen et al. (2008) & Gross & - & - & 2615 & 3187 & 3824 \\
\hline Shiklomanov $(2000 \mathrm{a}, \mathrm{b})$ & Withdrawal/Consumption & $1968 / 1086$ & $2526 / 1341$ & $3175 / 1686$ & $3633 / 1982$ & $3973 / 2182$ \\
\hline This study & Gross/Net & $1709 / 818$ & 2090/976 & $2708 / 1275$ & $3212 / 1456$ & $3708 / 1831$ \\
\hline
\end{tabular}

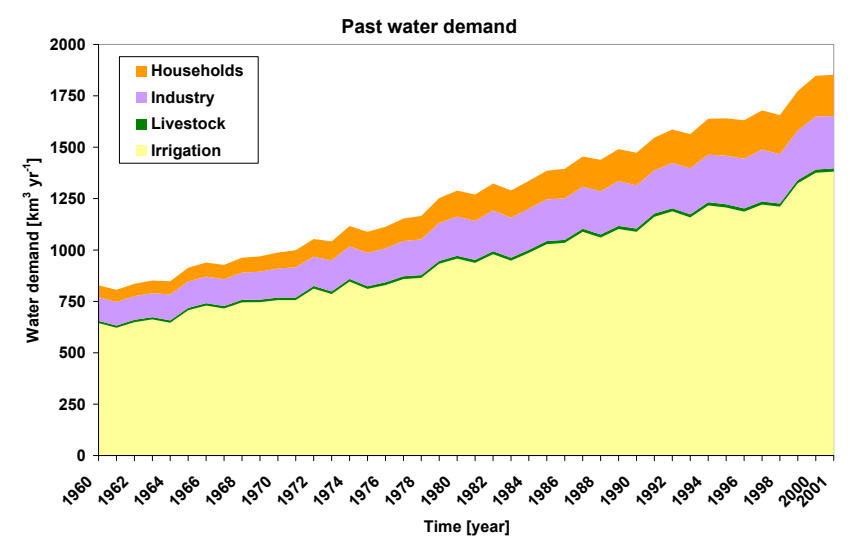

Fig. 4. Estimated net sectoral and total water demand from 1960 to 2001 in $\mathrm{km}^{3} \mathrm{yr}^{-1}$.

correlations are high for most countries, deviations are relatively large for several countries, e.g. Iraq, Lithuania, Puerto Rico, Mali, Djibouti and Bhutan.

\subsubsection{Total water demand}

The estimated gross/net total water demand doubled and reached $3708 / 1831 \mathrm{~km}^{3} \mathrm{yr}^{-1}$ for 2000 primarily due to the large increase in irrigation water demand (Table 3). Irrigation is responsible for $80 \%$ of the net total water demand (see Fig. 4) and is the cause of most of the heightened intensities of the demand in regions such as India, Pakistan, China, West and Central USA, Mexico, South Europe, the Middle East and Central Asia (see Fig. 5).

Comparison of estimated gross total water demand with reported total water withdrawal per country shows a good agreement, with $R^{2}$ ranging from 0.96 to 0.99 (see Fig. 3d; Table S4 in the Supplement). The deviations observed in the sectoral comparisons became less apparent when summed all the sectoral demands. For Greece and Iraq $(+50 \%)$, and Mali and Turkmenistan $(-40 \%)$, the deviations remain large. Additional comparisons of the gross and net total water demand with estimated water withdrawal and water consumption by Shiklomanov (2000a,b) also show good agreements for most of the countries, with $R^{2}$ ranging from 0.91 to 0.97 (see Fig. 6; Table S4 in the Supplement) and $\alpha$ ranging from 0.94 to 1.16. Our values are generally lower because of our lower irrigation water demand. 

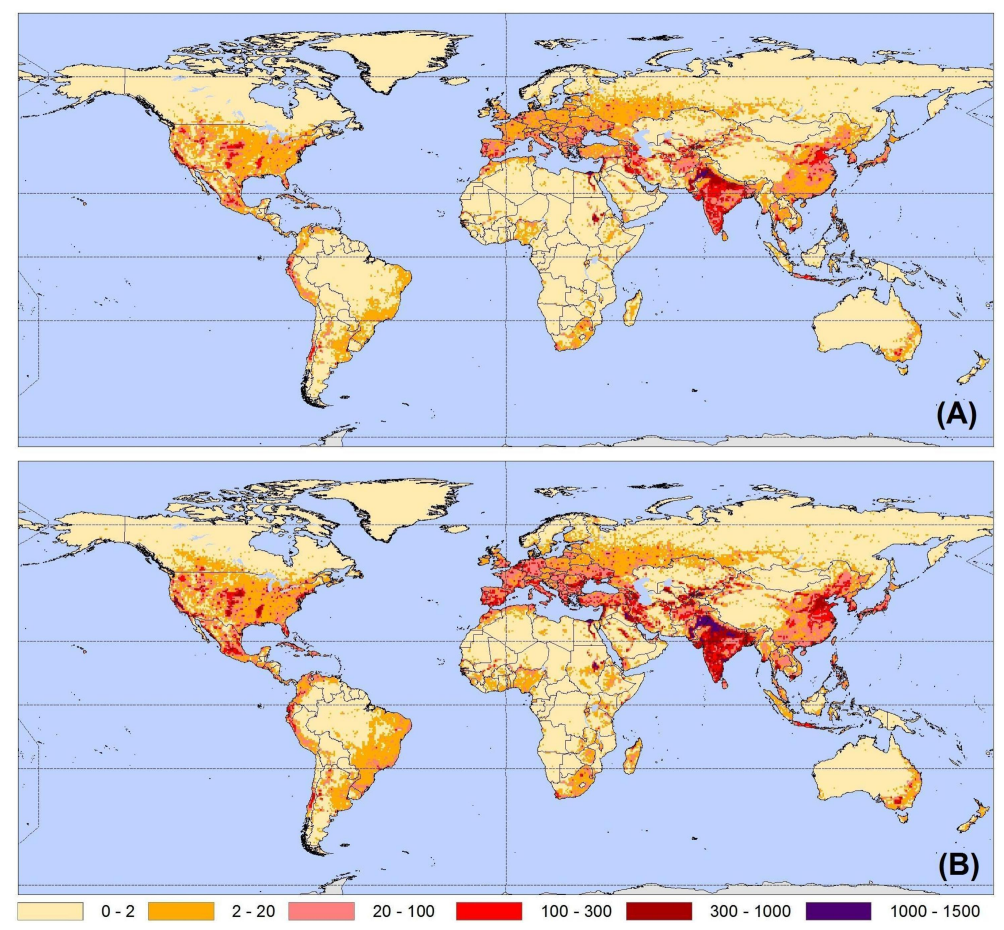

Fig. 5. Estimated net total water demand for (a) 1960 and (b) 2000 in million $\mathrm{m}^{3} \mathrm{yr}^{-1}$.
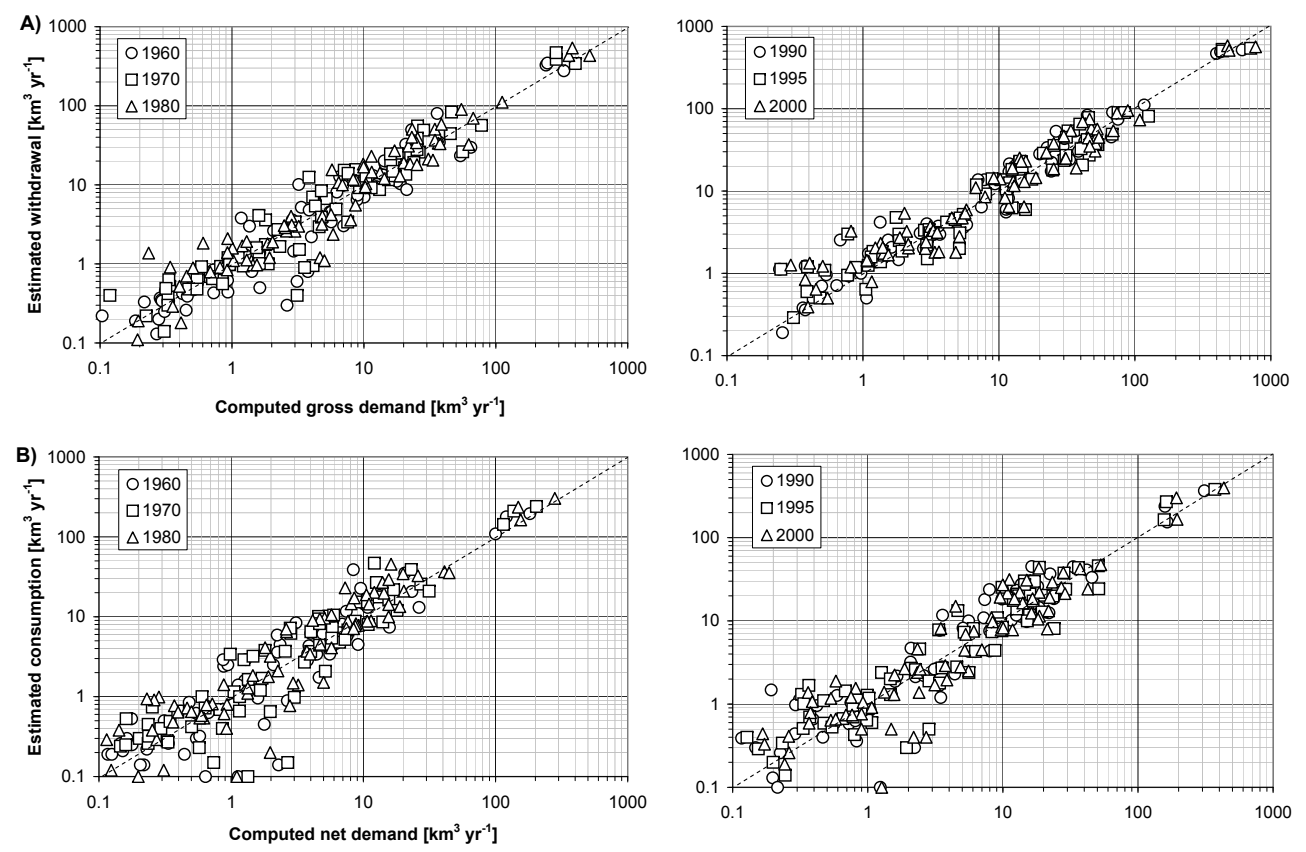

Fig. 6. Comparison between estimated (a) gross and (b) net total water demand (x-coordinate) and (a) water withdrawal and (b) water consumption (y-coordinate) per country from 1960 to 2000 in log-log plots. The estimated water withdrawals and water consumption were taken from Shiklomanov $(2000 \mathrm{a}, \mathrm{b})$. The dashed lines represent the 1:1 line. 
Table 4. Estimated total and non-renewable groundwater abstraction for major groundwater users from 1960 and 2000 . A comparison between this study and the model based estimates of P2011 (Pokhrel et al., 2011) is given for 2000.

\begin{tabular}{|c|c|c|c|c|c|c|c|c|}
\hline \multirow{3}{*}{$\frac{\mathrm{km}^{3} \mathrm{yr}^{-1}}{\text { Country }}$} & \multirow{2}{*}{\multicolumn{2}{|c|}{$\begin{array}{c}\text { Total [1] } \\
\text { This study }\end{array}$}} & \multicolumn{3}{|c|}{ Non-renewable [2] } & \multirow{2}{*}{\multicolumn{2}{|c|}{$\begin{array}{l}{[2] /[1](\%)} \\
\text { This study }\end{array}$}} & \multirow{3}{*}{$\begin{array}{r}\text { Increase in ratio }(\%) \\
\text { This study } \\
1960-2000\end{array}$} \\
\hline & & & \multicolumn{2}{|c|}{ This study } & \multirow{2}{*}{$\begin{array}{r}\text { P2011 } \\
2000\end{array}$} & & & \\
\hline & 1960 & 2000 & 1960 & 2000 & & 1960 & 2000 & \\
\hline India & 87 & 190 & 21 & 75 & 92 & 24 & 40 & 67 \\
\hline USA & 63 & 115 & 20 & 32 & 57 & 32 & 28 & -13 \\
\hline China & 46 & 97 & 10 & 25 & 20 & 22 & 26 & 18 \\
\hline Pakistan & 36 & 55 & 18 & 38 & 39 & 50 & 69 & 38 \\
\hline Iran & 31 & 53 & 12 & 28 & 33 & 39 & 53 & 36 \\
\hline Mexico & 18 & 38 & 5 & 12 & 22 & 28 & 32 & 14 \\
\hline Saudi Arabia & 5 & 21 & 2 & 15 & 14 & 40 & 71 & 78 \\
\hline Globe & 312 & 734 & 98 & 275 & 455 & 31 & 38 & 23 \\
\hline
\end{tabular}
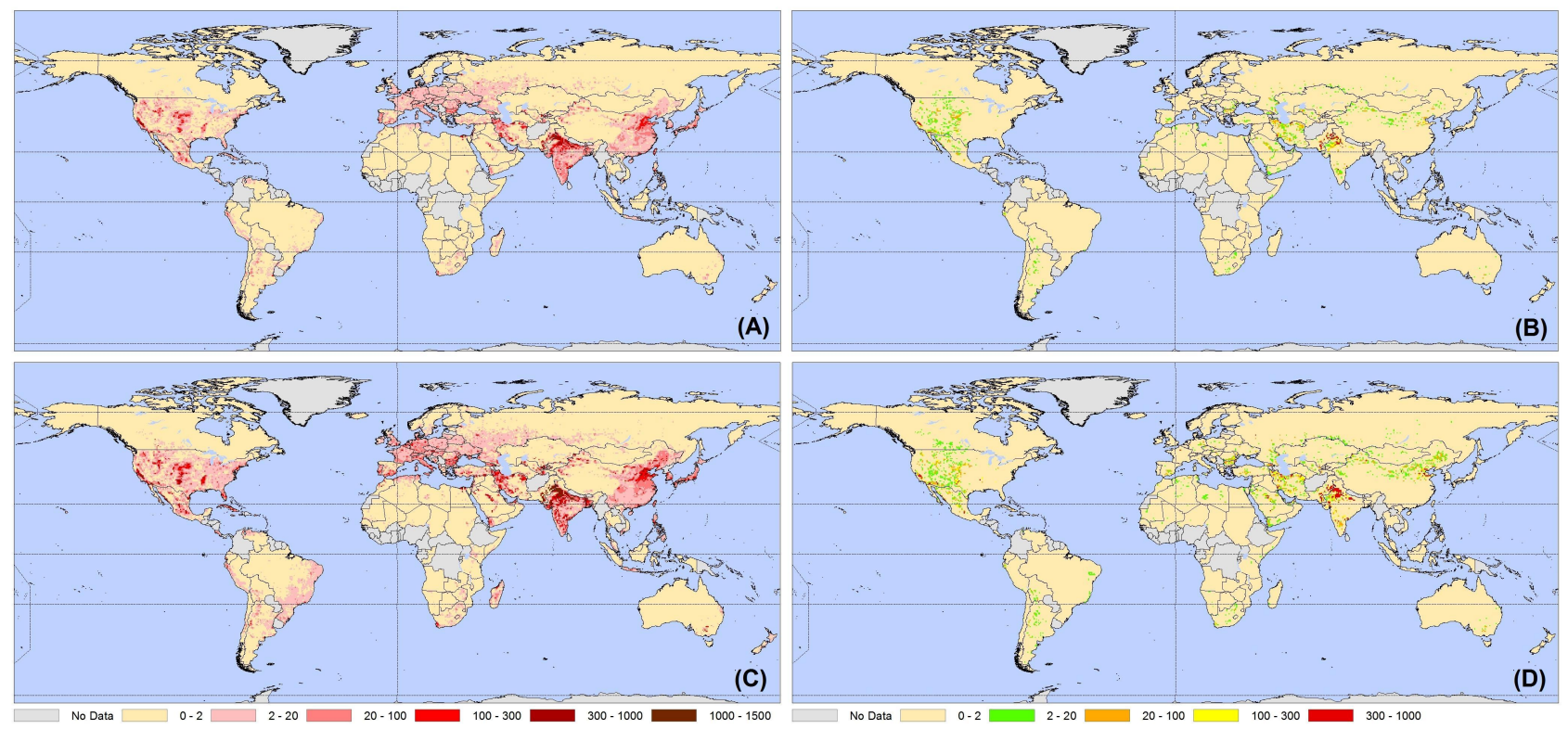

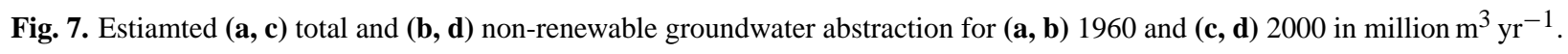

\subsection{Accuracy of blue water availability}

Climate variability as reflected by the inter- and sub-annual variability in blue water availability has a strong influence on our water stress assessment. Extensive validations of the estimates of PCR-GLOBWB were performed by Van Beek et al. (2011) by comparing the simulated river discharge to observations (Global Runoff Data Centre, 2008). We refer to Van Beek et al. (2011) for a detailed description of these validations. In brief, comparisons with over 3600 GRDC stations showed that $\mathrm{R}^{2}$ was high $(\approx 0.9)$ for most of the stations but $R^{2}$ decreased when the mean minimum and maximum monthly discharge were considered instead of the mean discharge. Inter-annual variability was mostly well reproduced in major rivers except the Niger $\left(R^{2}=0.54\right)$, Orange
( $\left.R^{2}=0.54\right)$, Murray $\left(R^{2}=0.60\right)$, Indus $\left(R^{2}=0.62\right)$, Zambezi $\left(R^{2}=0.75\right)$ and Nile $\left(R^{2}=0.87\right)$ where the simulated river discharge was often overestimated.

\subsection{Estimated non-renewable groundwater abstraction}

For 2000, our simulated groundwater recharge amounted to $15645 \mathrm{~km}^{3} \mathrm{yr}^{-1}$ to which natural recharge contributed $15225 \mathrm{~km}^{3} \mathrm{yr}^{-1}$ and return flow from irrigation contributed $420 \mathrm{~km}^{3} \mathrm{yr}^{-1}$ out of $1376 \mathrm{~km}^{3} \mathrm{yr}^{-1}$ irrigation water as additional recharge. Table 4 shows the estimated total and nonrenewable groundwater abstraction from 1960 to 2000. Estimated non-renewable groundwater abstraction nearly tripled over this period. Non-renewable groundwater abstraction considerably increased in India, East China, USA, Pakistan, 
Table 5. Simulated results of global population under different degrees of water stress from 1960 to 2000 with those of other studies. Per class, population is given in billions and the corresponding fraction of the global population (\%). Annual and sub-annual denote annual temporal assessment and sub-annual or monthly temporal assessment, respectively.

\begin{tabular}{|c|c|c|c|c|c|c|}
\hline \multirow{3}{*}{$\begin{array}{l}\text { Magnitude } \\
\text { Per capita water availability } \\
\left(\mathrm{m}^{3} \text { capita }^{-1} \mathrm{yr}^{-1}\right) \\
\text { WSI }\end{array}$} & \multirow{3}{*}{$\begin{array}{l}\text { No stress } \\
>1700 \\
\text { WSI }<0.1\end{array}$} & \multirow{2}{*}{$\begin{array}{l}\text { Low stress } \\
1700-1000\end{array}$} & \multirow{2}{*}{$\begin{array}{l}\text { Moderate } \\
\text { stress } \\
<1000\end{array}$} & \multirow[t]{2}{*}{ High stress } & \multirow{3}{*}{ Total } & \multirow{3}{*}{ Year } \\
\hline & & & & & & \\
\hline & & \multicolumn{3}{|c|}{$0.1 \leq \mathrm{WSI}<0.20 .2 \leq \mathrm{WSI}<0.4 \quad 0.4 \leq \mathrm{WSI}$} & & \\
\hline Vörösmarty et al. (2000) ${ }^{\text {annual }}$ & $3.2(55 \%)$ & $0.4(7 \%)$ & $0.4(7 \%)$ & $1.8(31 \%)$ & 5.8 & 1995 \\
\hline Oki et al. $(2001)^{\text {annual }}$ & $2.8(49 \%)$ & $0.6(11 \%)$ & $0.6(11 \%)$ & $1.7(30 \%)$ & 5.7 & 1995 \\
\hline Arnell $(2004)^{\text {annual }}$ & - & - & $0.8(14 \%)$ & $2.6(46 \%)$ & 5.7 & 1995 \\
\hline Hanasaki et al. $(2008 b)^{\text {sub-annual }}$ & $1.9(37 \%)$ & - & $0.9(17 \%)$ & $2.4(46 \%)$ & 5.2 & 1995 \\
\hline Alcamo et al. (2007) $)^{\text {annual }}$ & - & - & - & $2.3(40 \%)$ & 5.7 & 1995 \\
\hline Islam et al. $(2007)^{\text {annual }}$ & $3.8(62 \%)$ & $0.5(8 \%)$ & $0.6(10 \%)$ & $1.2(20 \%)$ & 6.1 & 2000 \\
\hline \multirow{5}{*}{ Kummu et al. $(2010)^{\text {annual }}$} & $1.52(92 \%)$ & \multicolumn{2}{|c|}{$0.10(6 \%)$} & $0.03(2 \%)$ & 1.7 & 1900 \\
\hline & $1.98(86 \%)$ & \multicolumn{2}{|c|}{$0.23(10 \%)$} & $0.09(4 \%)$ & 2.3 & 1940 \\
\hline & $2.41(81 \%)$ & \multicolumn{2}{|c|}{$0.29(10 \%)$} & $0.28(9 \%)$ & 3.0 & 1960 \\
\hline & $2.76(62 \%)$ & \multicolumn{2}{|c|}{$0.97(22 \%)$} & $0.71(16 \%)$ & 4.4 & 1980 \\
\hline & $3.21(50 \%)$ & \multicolumn{2}{|c|}{$0.95(15 \%)$} & $2.30(35 \%)$ & 6.5 & 2005 \\
\hline \multirow{5}{*}{ This study ${ }^{\text {annual }}$} & $2.4(80 \%)$ & $0.3(10 \%)$ & $0.1(3 \%)$ & $0.2(7 \%)$ & 3.0 & 1960 \\
\hline & $2.8(76 \%)$ & $0.3(8 \%)$ & $0.2(5 \%)$ & $0.4(11 \%)$ & 3.7 & 1970 \\
\hline & $3.2(73 \%)$ & $0.4(9 \%)$ & $0.3(7 \%)$ & $0.5(11 \%)$ & 4.4 & 1980 \\
\hline & $3.7(70 \%)$ & $0.5(9 \%)$ & $0.4(8 \%)$ & $0.7(13 \%)$ & 5.3 & 1990 \\
\hline & $3.8(62 \%)$ & $0.6(10 \%)$ & $0.5(8 \%)$ & $1.2(20 \%)$ & 6.1 & 2000 \\
\hline \multirow{5}{*}{ This study ${ }^{\text {sub-annual }}$} & $1.9(63 \%)$ & $0.3(10 \%)$ & $0.3(10 \%)$ & $0.5(17 \%)$ & 3.0 & 1960 \\
\hline & $2.2(59 \%)$ & $0.4(11 \%)$ & $0.4(11 \%)$ & $0.7(19 \%)$ & 3.7 & 1970 \\
\hline & $2.4(55 \%)$ & $0.5(11 \%)$ & $0.5(11 \%)$ & $1.0(23 \%)$ & 4.4 & 1980 \\
\hline & $2.8(53 \%)$ & $0.6(11 \%)$ & $0.7(13 \%)$ & $1.2(23 \%)$ & 5.3 & 1990 \\
\hline & $2.9(47 \%)$ & $0.6(10 \%)$ & $0.8(13 \%)$ & $1.8(30 \%)$ & 6.1 & 2000 \\
\hline
\end{tabular}

South Europe, South Mexico, North Iran and Central Saudi Arabia, primarily due to expansion of irrigated areas (see Fig. 7). The sum of non-renewable groundwater abstraction for these regions amounts to $90 \%$ of the global total. Compared to the model based estimates of Pokhrel et al. (2011) our values are generally smaller for most of the countries which are listed in Table 4. The difference can be explained by the fact that their estimates are based on the amount of water demand exceeding surface freshwater availability, which thus includes the estimates of not only nonrenewable groundwater abstraction but also potential nonlocal water resources, i.e. water use from cross-basin diversions or aqueducts, and desalinated water use. Building on previous work by Wada et al. (2010, 2011b), we included additional recharge from irrigation in our recharge estimate. This increases global recharge by $420 \mathrm{~km}^{3} \mathrm{yr}^{-1}$ and reduces the amount of non-renewable groundwater abstraction from 309 to $275 \mathrm{~km}^{3} \mathrm{yr}^{-1}$. This improvement subsequently mitigated or removed some of hotspots, notably in South California and along the Indus, where the amounts were likely overestimated by earlier studies (Wada et al., 2010, 2011) (Fig. 7).

\subsection{Development of past water stress}

Table 5 shows the global population under different degrees of water stress from 1960 to 2000. For around 2000, our value for the global population under high water stress (WSI $\geq 0.4$ ) is in line with those of previous studies (e.g. Vörösmarty et al., 2000; Oki et al., 2001). Compared to these studies, we accounted for desalinated water use and non-renewable groundwater abstraction, which subsequently lowered blue water demand (see Eq. 1). Yet, our results returned somewhat higher values compared to some of the previous studies (e.g. Oki et al., 2001; Islam et al., 2007). This is because sub-annual assessment captures seasonal variations of water stress and returns higher values (Hanasaki et al., 2008b; Wada et al., 2011b). When compared to Kummu et al. (2010), our results generally show a larger share of the global population under water stress mainly due to our finer temporal and spatial resolution. In addition, our numbers are larger in regions where relatively small population sizes yet intensive irrigation occur such as Central USA, Central Asia and parts of Australia since we included extent of irrigated areas, while Kummu et al. (2010) computed water demand 

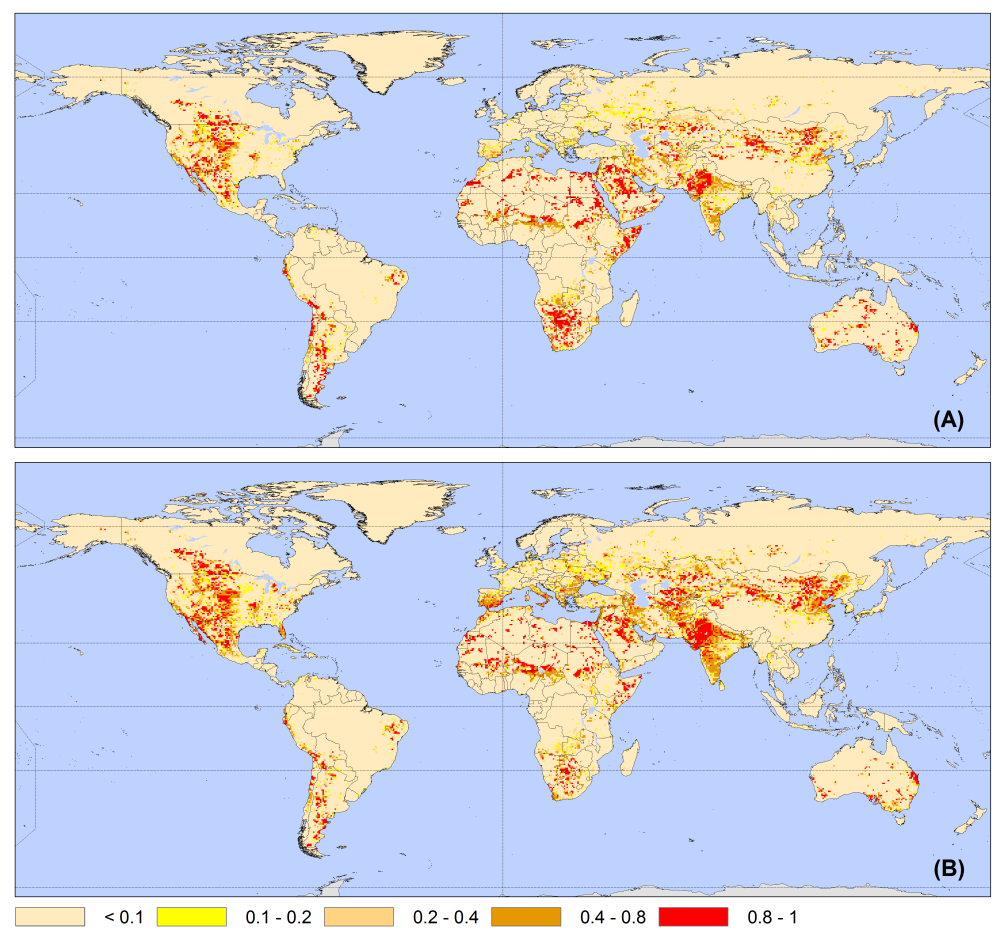

Fig. 8. Simulated global water stress (-) for (a) 1960 and (b) 2000.

based on population sizes to assess water stress. Long-term trends show a drastic increase in the global population living under water-stressed conditions (i.e. moderate to high water stress). For 1960, 800 million people or $27 \%$ of the global population are living under water-stressed conditions. This figure increases to 1.1 billion or $30 \%, 1.5$ billion or $34 \%$ and 1.9 billion or $36 \%$ for 1970,1980 and 1990 , respectively. The global population living under water-stressed conditions eventually amounts to 2.6 billion or $43 \%$ for 2000 . While the number of people experiencing moderate water stress rises from 300 to 800 million over the period 1960-2000, that experiencing high water stress soars from 500 million to 1.8 billion, one-third of the global population. Although the global population increased by around 700 million per decade, the rapid increase of the global population under high water stress indicates a worsened condition and severer competition for global surface freshwater resources.

\subsection{Heightened water stress in relation to growing water demand and climate variability: global analysis}

High water stress occurs mainly over heavily irrigated, densely populated and/or water scarce regions, e.g. Central and South Asia, China, South Europe, USA, Mexico and the MENA (the Middle East and North Africa) region. Many of those regions already experienced high water stress before 1960, but the intensities significantly increase towards 2000 (see Fig. 8). East to South Europe is experiencing high water stress for 2000 .

The result of the linear regression (see Sect. 2.2) to distinguish the contribution of climate variability and growing water demand to heightened water stress is shown in Fig. 9. Over India, North East China, Central Asia, South Europe and the Sahel, decreased water availability increased water stress by 0.1 to 0.2 (Fig. 9a). In these regions, maximum water stress was also intensified by decreased water availability (Fig. 9c). In fact, India experienced decreased rainfall between 1960 and 2001 during the winter and pre-monsoon season (Joshi and Rajeevan, 2006; Guhathakurta and Rajeevan, 2006) in which the highest water stress generally occurs. North East China experienced a higher frequency of extreme dry conditions during the late 20th century (Shen et al., 2007; Zhuguo et al., 2004). South Europe experienced dry conditions over the 1980s and 1990s and the Sahel suffered from long-term droughts during the 1970s and late 1980s (Sheffield and Wood, 2007).

Figure $9 \mathrm{~b}$ shows that the impact of increased water demand on heightened water stress. Increased water demand has a dominant effect on heightened water stress for India, China, Mexico, South Europe and Central Asia. In these regions, water stress was intensified by $0.2-0.8$ due to increased water demand. Increased water demand also intensified maximum water stress by 0.2 to 0.4 for North East China, Central India, Central Asia and East and South 

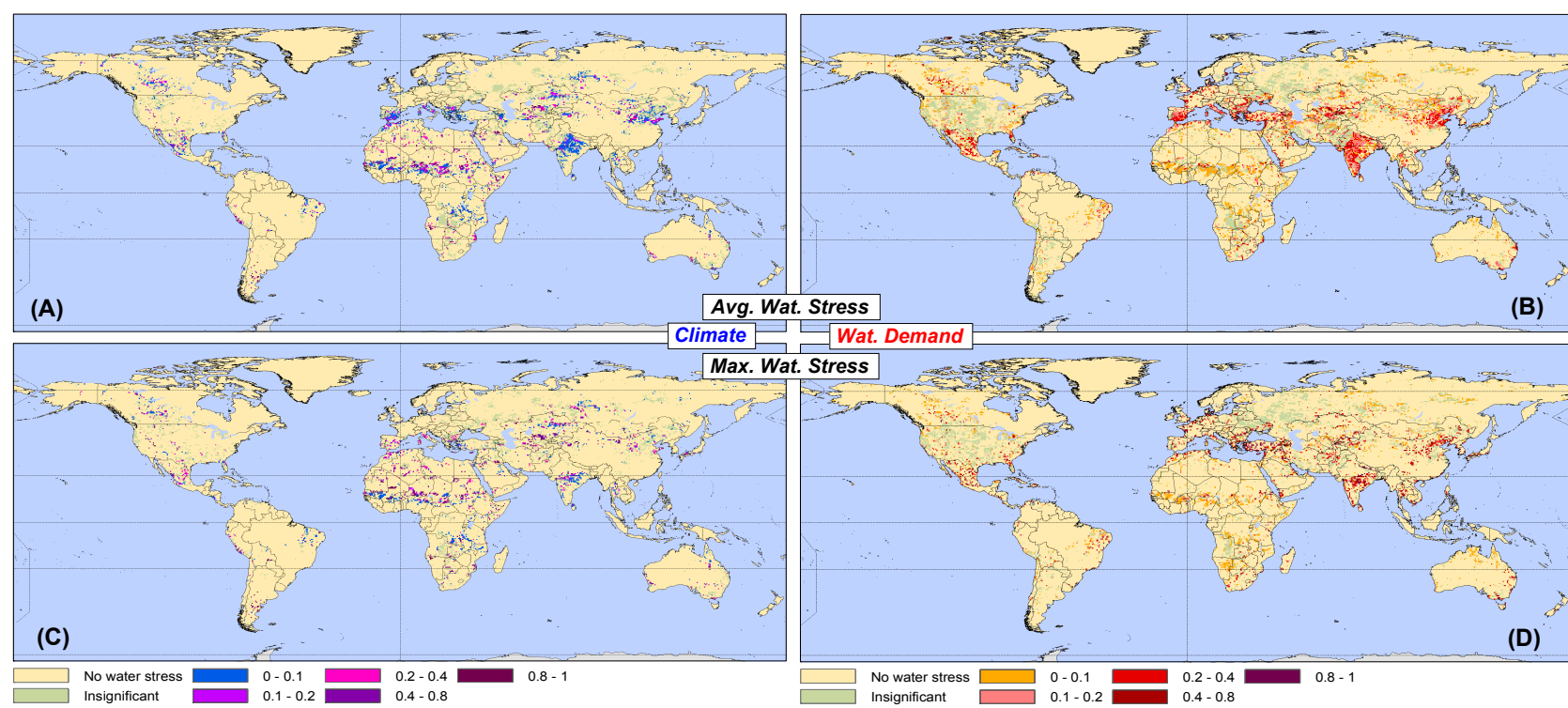

(B)

Fig. 9. Contribution to heightened water stress (-) due to $(\mathbf{a}, \mathbf{c})$ decreased water availability and $(\mathbf{b}, \mathbf{d})$ increased water demand. Yearly $(\mathbf{a}$, b) average and (c, d) maximum water stress were used to estimate the trends between 1960 and 2001 by linear regression (two-tailed t-test with $\alpha=0.05$ ).

Europe (Fig. 9d). To grasp the contribution of sectoral water demand to heightened water stress, Fig. 10 shows regional trends in net sectoral over the period 1960-2001. For India, irrigation water demand amounts to $90 \%$ of total water demand and has nearly tripled over this period. Irrigation water demand is also dominant (70-90\%) for China, Central and Western Asia (e.g. Iran and Turkey), Southern Europe (e.g. Spain and Italy) and Central America (e.g. Mexico). Drastic increase of irrigation water demand thus explains the cause of heightened water stress in most of these regions. Industrial water demand amounts to more than $50 \%$ of total water demand in Northern, Central and Eastern Europe, Russia and Canada while domestic water demand shares more than $30 \%$ in Eastern Asia, North Eastern Europe, Central Africa, Eastern South America and Oceania.

Overall, the results suggest that increased water demand is the decisive factor for heightened water stress throughout the globe, except for the Sahel where decreased water availability has a larger impact. This can be explained by the fact that in the Sahel water demand is substantially lower compared to the other water-stressed regions.

\subsection{Development of water stress in relation to growing water demand and climate variability: country analysis}

Here we show monthly time series of past water stress. For several countries and states, we compare the results of two simulation runs, i.e. transient water stress and water stress with fixed water demand for 1960 (see Sect. 2.2) to assess detrimental effects of climate variability and increased water demand on water stress. To obtain a country or state WSI, we averaged the simulated WSI for all pertinent cells, which may suppress water stress that occurs in a particular part of the domain (see Fig. S2; Supplement). We selected several emerging and developing countries where water demand increased rapidly over the period 1960-2001: Mexico, Kerala (India), Shanxi (China), Turkey, Romania, Bulgaria and Cuba.

As a limited validation exercise, we compare monthly time series of past water stress with reported periods of major droughts for those countries and states. It should, however, be noted that our simulated water stress is not congruent in definition with observed droughts. Droughts are generally classified into four categories; meteorological, hydrological, agricultural and socio-economic drought (Wilhite and Glantz, 1985; Mishra and Singh, 2010). Our water stress is defined by net total blue water demand and blue water availability (see Eq. 1). High water stress can thus be seen as hydrological in combination with socio-economic drought, while we also consider meteorological effects when we compute irrigation water demand by using available local green water. Observed droughts were recorded for individual countries and states by different methods (e.g. PDSI: Palmer Drought Severity Index and SPI: Standard Precipitation Index) by different studies. As a result, in the following sections, comparisons between simulated water stress and observed droughts are rather qualitative than quantitative, in which we try to assess our performance in relation to extreme events only. 


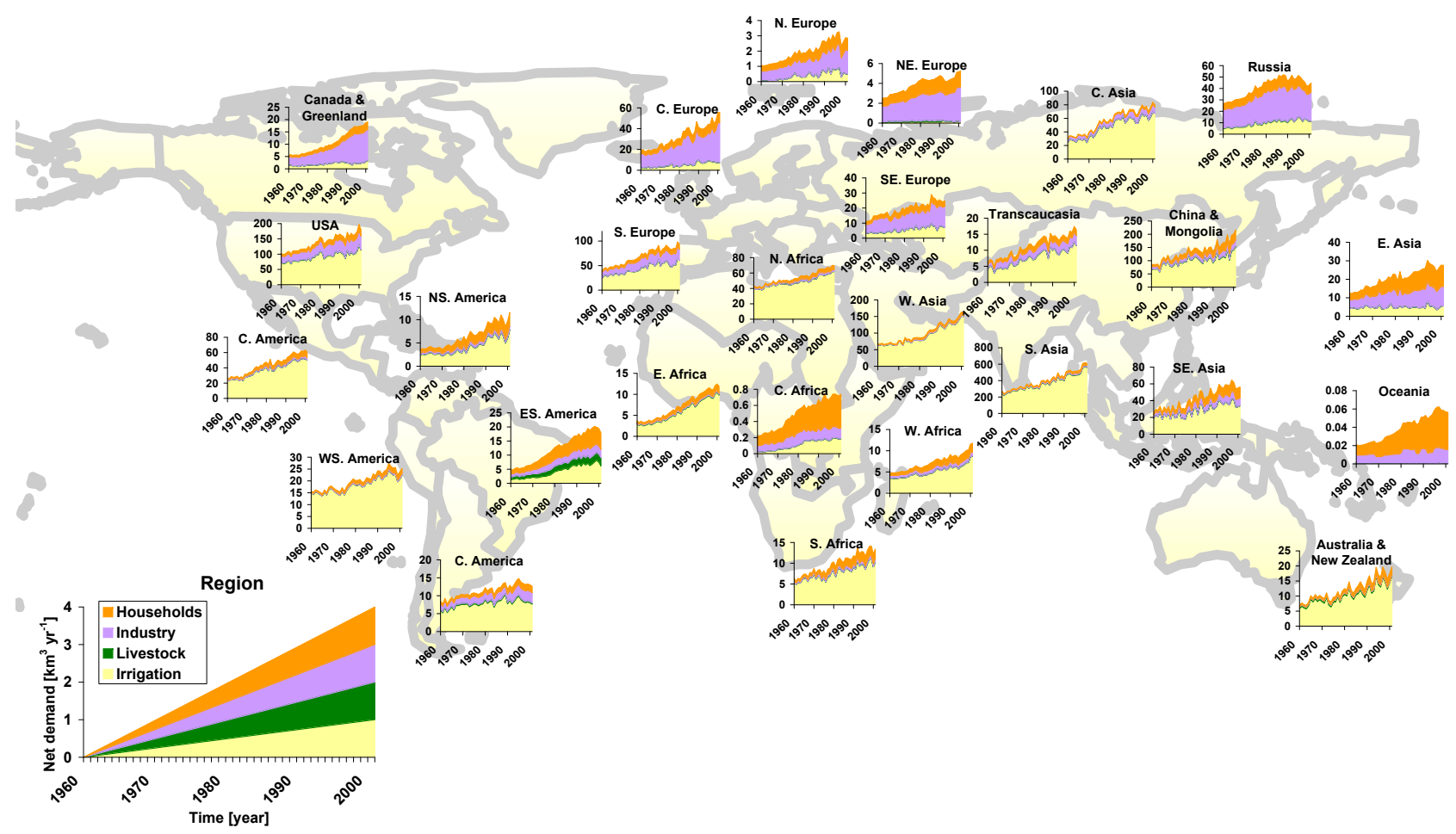

Fig. 10. Regional trends in net sectoral and total water demand over the period 1960-2001. Countries were aggregated to 27 regions. Sectoral water demand is shown by cumulative filled area chart (y-coordinate; $\mathrm{km}^{3} \mathrm{yr}^{-1}$ ) per region. Abbreviations used: N.: North; S.: South; E.: East; W.: West; C.: Central; NE.: North East; SE.: South East; NS.: North South; ES.: East South; WS.: West South.

\subsubsection{Mexico}

Mexico is characterized by (semi-)arid climate and has a long experience with drought (Liverman, 2000). The climate varies significantly across Mexico where most of the rainfall occurs in a rainy season between June and September. Mexico suffers persistent droughts partly associated with El Niño Southern Oscillation (ENSO). Based on PDSI, major droughts occurred during the periods 1969-1979, 19821984, 1987-1988 and 1994-2003 (Liverman, 2000; Stahle et al., 2009). Our simulated WSI also show higher water stress in these periods (Fig. 11a). In addition, our results indicate that in Mexico water demand was doubled over the period 1960-2001 due to a large increase in irrigation water demand. Results from two simulation runs clearly show that water stress was aggravated by increased water demand (up to $35 \%$ ) particularly after the mid-1990s.

\subsubsection{Kerala (India)}

Kerala, a state in South West India, is characterized by a tropical monsoon climate. The state receives excessive rainfall during the monsoon season (May-September) which contributes more than $80 \%$ of the annual rainfall. It also suffers from periodic drought conditions (Nathan, 2000), primarily due to rainfall deficits and late onsets of the monsoon. Kerala experienced major meteorological droughts during the periods 1982-1983, mid 1980s-early 1990 s and late 1990searly 2000s (Nathan, 2000; Simon and Mohankumar, 2004; Tyagi et al., 2006). Our results confirm above-average water stress for these periods (Fig. 11b). Our results also indicate a large impact of increased water demand on water stress. For example, WSI stays as low as 0.1 for 2000 when water demand remains the same amount as that for 1960. Water demand tripled over the period 1960-2001 and aggravated water stress by up to $200 \%$, particularly after the mid-1980s. Water demand has been a dominant factor for the high intensities of water stress in Kerala.

\subsubsection{Shanxi (China)}

Shanxi, a province in North East China, is characterized by continental monsoon climate. Average annual precipitation varies between 400 and $600 \mathrm{~mm}$ within the province. Climate records suggest that 1966 was the driest year in North East China during the 20th century (Shen et al., 2007). Many parts of North East China also suffered major meteorological droughts during the period 1972, 1978, 1987-1988, 1991-1992, 1997 and 2000-2001 (Zhuguo et al., 2004; Shen et al., 2007). Our simulated WSI also captures these years (Fig. 11c). In climate sense, 1966 was the driest year over the period 1960-2001, however, interestingly WSI shows the 

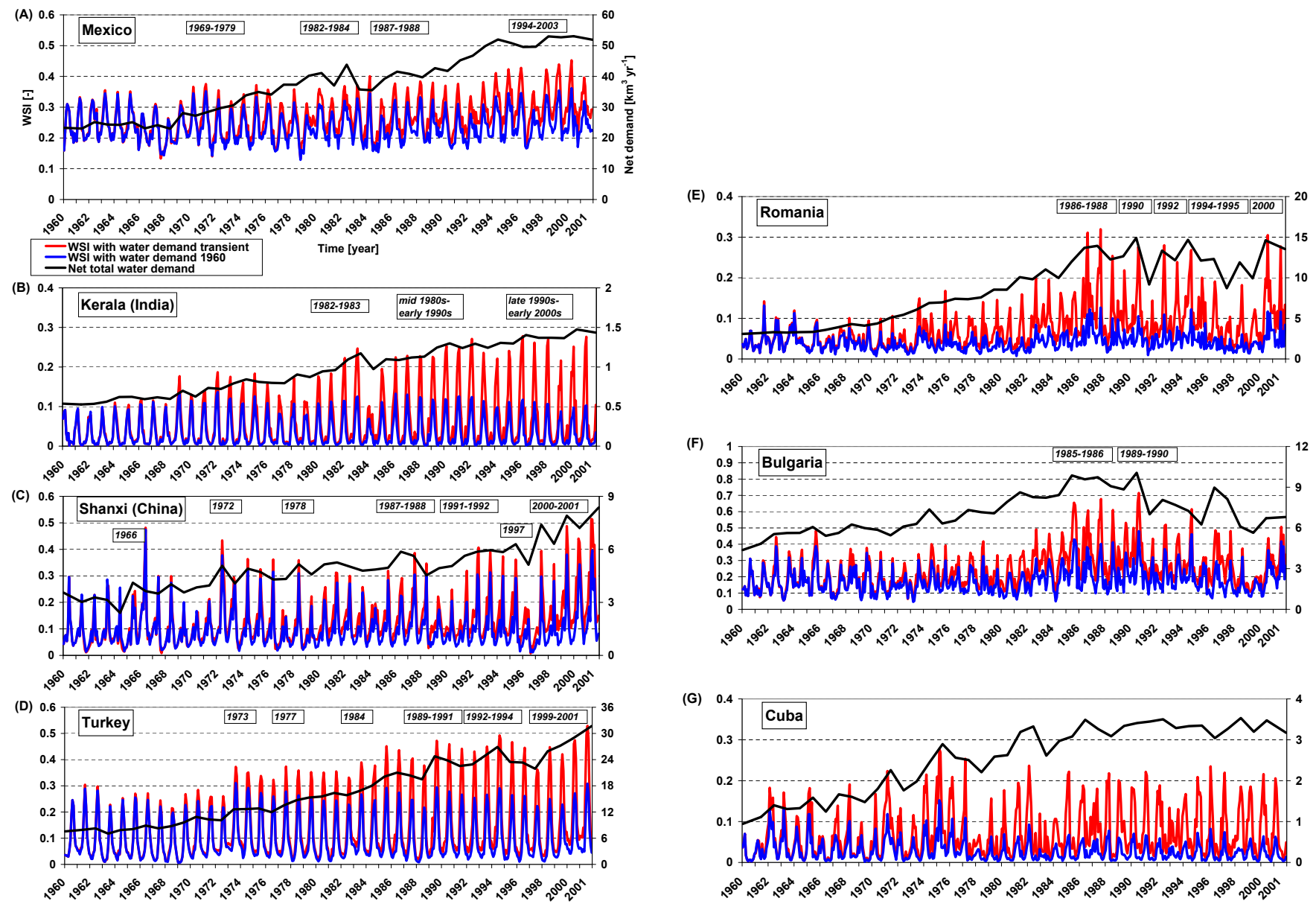

Fig. 11. Comparisons of simulated country-averaged monthly water scarcity index (WSI; left y-coordinate; dimensionless) between that with the estimated water demand for each year and that with the estimated water demand for 1960 over 1960-2001 for (a) Mexico, (b) Kerala (India), (c) Shanxi (China), (d) Turkey, (e) Romania, (f) Bulgaria, and (g) Cuba. The estimated net total water demand is shown over the same period (right y-coordinate; $\mathrm{km}^{3} \mathrm{yr}^{-1}$ ).

highest peak for 2001 rather than 1966. This is a result of increased water demand which was doubled over the period. Water stress was thus exacerbated by increased water demand (up to $40 \%$ ).

\subsubsection{Turkey}

Turkey is characterized by temperate Mediterranean climate and has a dry summer followed by a wet winter. The country is exposed to recurrent droughts partly due to unevenly distributed precipitation within the territory, where the central parts annually receive around $500 \mathrm{~mm}$ while coastal parts annually enjoy more than $1000 \mathrm{~mm}$. After a major wet period 1962-1970 persistent dry conditions started after the mid-1970s and major meteorological droughts resulted in 1973, 1977, 1984, 1989-1991, 1992-1994 and 1999-2001 (Türkes, 1996; Komuscu, 2001; Yildiz, 2009). Although 1973 was the driest year (Türkes, 1996), our simulated WSI persistently show severer water stress after the mid-1980s
(Fig. 11d). Increased irrigation water demand contributed most of the heightened water demand. The increased water demand consistently intensified the severity of water stress by more than $50 \%$ after the mid-1980s.

\subsubsection{Romania}

Romania, in South East Europe, has a temperate to continental climate, with varying annual precipitation from 400 to more than $1000 \mathrm{~mm}$. Nearly half of the country's surface freshwater is supplied by the Danube River. In 1970 Romania suffered from extensive floods due to excessive rainfall in combination with snowmelt while the country experienced major meteorological droughts during the periods 1986-1988, 1990, 1992, 1994-1995 and 2000 (Sandu and Mateescu, 2009; Mihailescu et al., 2010). Our simulated WSI also shows higher water stress in these periods (Fig. 11e). When compared results of two simulation runs, we found a large impact of increased water demand on WSI. 
It can be seen that after the 1980s water stress is primarily driven by an anthropogenic cause, i.e. heightened water demand, rather than climate variability. Our estimated water demand quintupled between 1960 and 2001. Zavoianu (1993) also reports a drastic increase of water use between 1950 and 1990. Agricultural water demand amounts to half of the total water demand and exhibits a large inter-annual variability, i.e. larger green water availability as a result of above average rainfall reduced irrigation water demand notably in 1991, 1997 and 1999.

\subsubsection{Bulgaria}

Bulgaria, a southern neighbour of Romania, suffers from frequent droughts. Climate records indicate that precipitation was in a decreasing trend after the early 1980s until the early 2000 s, where annual precipitation was $80 \%$ of the normal during the period (Alexandrov and Genev, 2003; Knight et al., 2004; Koleva and Alexandrov, 2008). As a result, prolonged meteorological droughts occurred during the period 1982-1994 in which droughts of 1985-1986 and 1989-1990 were particularly severe (Knight et al., 2004). Our simulated WSI confirms heightened water stress during the same period (Fig. 11f), but also suggests that during the 1980s water stress was intensified by $50 \%$ as a result of increased water demand. Water demand reached a peak during the 1980s but diminished after the 1990s due to decreased overall usage. This subsequently reduced the intensity of water stress.

\subsubsection{Cuba}

Cuba, located in the North Caribbean Sea, has moderate (sub-)tropical climate. The wet season starts in May and continues until October followed by a dry season. Cuba receives abundant rainfall which annually exceeds $1300 \mathrm{~mm}$ but also faces water scarcity in the dry season (Naranjo-Diaz and Pérez, 2007). Freshwater withdrawal, being one of the highest in the Caribbean, substantially increased from 8 to $13 \mathrm{~km}^{3} \mathrm{yr}^{-1}$ over the period $1975-1990$, mainly due to irrigation, because Cuba increased irrigated areas for waterconsuming crops such as rice and sugarcane (United States Department of Agriculture, 2008). The increase in the freshwater withdrawal diminished after the 1990s along with the country's economic decline. Our estimated water demand is in line with those of United States Department of Agriculture (2008) and the FAO AQUASTAT data base. Our results indicate that increased water demand considerably worsened Cuba's water stress after the 1970 s (100\% up to $200 \%)$ as shown in Fig. 11g. After the 1980s, WSI has been nearly tripled due to heightened water demand. These results thus show the dominant role of agricultural water use in aggravating Cuba's water scarcity, while climate variability has only a minor impact.

\section{Discussion}

We here assess uncertainty and address the limitations inherent to this study. Various uncertainties associate with the methodologies and data employed in this study. We combined the available global gridded data sets with the country statistics to compute sectoral water demand. Irrigation water demand, being by far the largest demand, is a major source of uncertainty. A previous study of Wisser et al. (2008) observed $30 \%$ increase of the global irrigation water demand by using the irrigated areas of Thenkabail et al. (2006) over that of Siebert et al. $(2005,2007)$. They also found $30 \%$ decrease of the global irrigation water demand by using the climate data of NCEP/NCAR compared to that of CRU (see Table S1 in the Supplement). The results also vary by $20 \%$ when the FAO Penman-Monteith method or the PriestleyTaylor method is used to compute reference (potential) evapotranspiration (Siebert and Döll, 2010). The use of efficiency factors and the inclusion of green water availability by irrigated crops provide further sources of uncertainties (Wada et al., 2011b). The results also vary with/without considering contributions of non-renewable and non-local blue water (IPOT/ILIM; cf. Rost et al., 2008). Furthermore, our past extents of irrigated areas are based on the country statistics but were distributed to $0.5^{\circ}$ by using the present gridded irrigated areas. This method is unable to reproduce changes in the distribution within countries, which causes significant uncertainties primarily before the 1970 s when many countries initiated intensive irrigation developments. However, it adequately reflects the large-scale dynamics of the expanding irrigated areas over the past decades (Wisser et al., 2010). The comparisons of estimated irrigation water demand with reported values show good agreement for most of the countries, while large deviations were observed for several countries where irrigated areas are likely overestimated (e.g. Iraq).

Past economic development was approximated using GDP, electricity production, energy and household consumption, which produces another source of uncertainty. For instance, we observed large deviations in estimated gross industrial and domestic water demand in comparison with reported water withdrawal for some of Middle American countries, where the computed WUI (see Sect. 2.3.3) may need to be adjusted. The interpolated recycling ratios which account for return flow from industrial and domestic sectors also cause uncertainties, but compared to errors in irrigation water demand, their potential errors are small due to the smaller sectoral demand. Our recycling ratios were set lower than Shiklomanov (2000b) who proposes global averages of $90 \%$ and $85 \%$ for industrial and domestic sector. These recycling ratios might be too optimistic particularly for developing countries with a low technological capability, where water recycling efficiency is expected to be lower compared to that for developed countries. Wada et al. (2011b) indicated that the recycling ratio increased from $40 \%$ to $80 \%$ over the period 1960-2001 in Japan. Despite these uncertainties, estimated 
demands overall agree well with reported values for most of the countries.

Estimated groundwater abstraction is subject to large uncertainties. For instance, a considerable part of groundwater abstraction in major irrigated regions, such as North West India and North East Pakistan, may remain unreported. We used groundwater abstraction of $190 \mathrm{~km}^{3}$ for 2000 for India while Foster and Loucks (2006) suggest $240 \mathrm{~km}^{3}$. Given the fact that non-reported groundwater abstraction may be prevalent, implicit methods to estimate groundwater abstraction (e.g. Vörösmarty et al., 2005; Rost et al., 2008; Wisser et al., 2010; Hanasaki et al., 2010) have a clear advantage in countries where no abstraction rates have been reported. However, potential errors in these methods might be large given the considerable variation among these estimates (see Table S3; Supplement). We therefore opted to use the country statistics regardless of the missing values in several countries (e.g. Afghanistan and the Former Yugoslavia).

We used gross water demand as an estimate of water withdrawal and net water demand as that of consumptive water use as usually done in most of previous studies (e.g. Döll and Lehner, 2002; Wisser et al., 2008; Wada et al., 2011b). This potentially leads to an overestimation because actual withdrawal and consumption may be lower as a result of physical, technological or socio-economic limitations that exist in various countries. However, comparison of estimated gross water demand with reported water withdrawal and estimated net water demand with consumptive water use estimates show overall good agreement. This consequently increases our confidence on the results but further improvements of water demand estimates undoubtedly increase the accuracy of water stress assessments.

Our selected spatial scale $\left(0.5^{\circ}\right)$ also affects our results. Since our global model does not include cross-basin diversions (e.g. aqueducts), underestimation of blue water availability occurs in some regions notably in India (e.g. aqueducts from Yamuna River) and West USA (e.g. Central Valley Project) where extensive diversion works are present. Yet, data for such information is very limited. In addition, it is difficult to assess the amount of water actually transferred by canals from their maximum capacity, e.g. Periyar Project in South India: $40 \mathrm{~m}^{3} \mathrm{~s}^{-1}$, Kurnool Cudappah Canal in South India: $85 \mathrm{~m}^{3} \mathrm{~s}^{-1}$, Irtysh-Karaganda Canal: $75 \mathrm{~m}^{3} \mathrm{~s}^{-1}$ (World Bank; http://www.worldbank.org/; UNDP; http://www.undp.org). As a result, our simulated water stress is likely overestimated in those regions.

Although the virtual water trade was not assessed in this study, it is becoming an important factor affecting regional and global water resources management, and consequently water scarcity. The international food trade has allowed for a disproportionate growth in some dryland populations, which can rely on a regular basis on food produced in other regions (Allan, 1998; D'Odorico et al., 2010). Yet, most of the virtual water flows are currently driven by geographical, political and economical factors (Suweis et al., 2011). Some of high water stressed countries, e.g. India and Pakistan, are the net virtual water exporter in crop trade (Hoekstra and Hung, 2005). In these regions, population is projected to grow, which will thus increase water demand. Future assessment of water scarcity with regard to the virtual water trade is of scientific importance.

\section{Summary and conclusions}

To assess the development of blue water stress over the recent past (1960-2001), we developed a method to reconstruct past water demand and confronted it against the blue water availability simulated by the state-of-the-art global hydrological model PCR-GLOBWB. The comparisons of the reconstructed water demand with reported statistics and available estimates show good agreement throughout the period. This subsequently increases our confidence in resulting water stress assessment. Similar to Kummu et al. (2010), our results show a drastic increase of the global population under moderate to high water stress due to increased water demand during the period 1960-2001. We estimate that 800 million people or $27 \%$ of the global population were living under water-stressed conditions for 1960 . This number eventually increased to 2.6 billion or $43 \%$ for 2000 . Increased irrigation water demand associated with the rapid population rise globally contributes much of the heightened water stress. Time series of simulated country-average WSI are consistent with reported periods of major meteorological droughts in selected countries and states. These results show that increased water demand has a considerable impact on heightened water stress while climate variability is often a main determinant of extreme events. However, our results also indicate that in several countries (e.g. India, Turkey, Romania and Cuba) some of past observed extreme events are anthropogenically driven due to increased water demand rather than being climate-induced.

In conclusion, this study quantified the past trajectories of water demand and climate variability that are liable to lead to heightened water stress. We also explored new data sources, approaches to assess water stress and highlights sources of uncertainty that may assist to increase the reliability of future studies on water stress. Our results show a strong anthropogenic intensification by human water use on water stress in several countries (e.g. India, Turkey, Romania, Bulgaria and Cuba) which underwent a consistent water demand growth over the period 1960-2001. In those countries climate variability has a relatively minor impact on water stress. Thus, further increase in water demand will undoubtedly exacerbate future potential water stress. It is clear that managing water demand is a key factor to ease regional water scarcity. 


\section{Supplementary material related to this article is available online at: http://www.hydrol-earth-syst-sci.net/15/3785/2011/ hess-15-3785-2011-supplement.pdf.}

Acknowledgements. We wish to thank four anonymous reviewers and an editor for their constructive comments and thoughtful suggestions, which substantially helped to improve the quality of this manuscript. This research benefited greatly from the availability of invaluable data sets as acknowledged in the references. This study was financially supported by Research Focus Earth and Sustainability of Utrecht University (Project FM0906: Global Assessment of Water Resources).

Edited by: N. Basu

\section{References}

Alcamo, J., Henrichs, T., and Rösch, T.: World Water in 2025 Global modeling and scenario analysis for the World Commission on Water for the 21st Century, Kassel World Water Series 2, Center for Environmental Systems Research, University of Kassel, Germany, 2000.

Alcamo, J., Flörke, M., and Märker, M.: Future long-term changes in global water resources driven by socio-economic and climatic changes, Hydrol. Sci. J., 52, 247-275, 2007.

Alexandrov, V. and Genev, M.: Climate Variability and Change Impact on Water Resources in Bulgaria, European Water, 1, 25-30, 2003.

Allan, J. A.: Virtual water: A strategic resource global solutions to regional deficits, Ground Water, 36, 545-546, doi:10.1111/j.1745-6584.1998.tb02825.x, 1998.

Allen, R. G., Pereira, L. S., Raes, D., and Smith, M.: Crop evapotranspiration - Guidelines for computing crop water requirements, FAO Irrigation and Drainage Paper 56, FAO, Rome, 1998.

Arnell, N. W.: Climate change and global water resources, Global Environ. Change, 9, 31-49, 1999.

Arnell, N. W.: Climate change and global water resources: SRES emissions and socio-economic scenarios, Global Environ. Change, 14, 31-52, 2004.

Bondeau, A., Smith, P. C., Zaehle, S., Schaphoff, S., Lucht, W., Cramer, W., Gerten, D., Reichstein, M., and Smith, B.: Modelling the role of agriculture for the 20th century, Global Change Biol., 13, 679-706, doi:10.1111/j.13652486.2006.01305.x, 2007.

Chao, B. F., Wu, Y. H., and Li, Y. S.: Impact of artificial reservoir water impoundment on global sea level, Science, 320, 212-214, doi:10.1126/science.1154580, 2008.

Chow, V. T., Maidment, D. R., and Mays, L. W.: Applied Hydrology, McGraw-Hill, New York, USA, 1988.

D'Odorico, P., Laio, F., and Ridolfi, L.: Does globalization of water reduce societal resilience to drought?, Geophys. Res. Lett., 37, L13403, doi:10.1029/2010GL043167, 2010.

Döll, P. and Lehner, B.: Validating of a new global 30-minute drainage direction map, J. Hydrol., 258, 214-231, 2002.

Döll, P. and Siebert, S.: Global modeling of irrigation water requirements, Water Resour. Res., 38, 8.1-8.10, doi:10.1029/2001WR000355, 2002.
Döll, P., Kaspar, F., and Lehner, B.: A global hydrological model for deriving water availability indicators: model tuning and validation, J. Hydrol., 270, 105-134, 2003.

Döll, P., Fiedler, K., and Zhang, J.: Global-scale analysis of river flow alterations due to water withdrawals and reservoirs, Hydrol. Earth Syst. Sci., 13, 2413-2432, doi:10.5194/hess-13-24132009, 2009.

Els, A. J. E. and Rowntree, K. M.: Water resources in the sanannah regions of Botswana, Tech. rep., EU INCO/UNEP/SCOPE Southern African Savannas Project, 2003.

Falkenmark, M.: The massive water scarcity now threatening Africa-why isn't it being addressed?, Ambio, 18, 112-118, 1989.

Falkenmark, M., Kijne, J. W., Taron, B., Murdoch, G., Sivakumar, M. V. K., and Craswell, E.: Meeting Water Requirements of an Expanding World Population [and Discussion], Philos. T. Roy. Soc. Lond. B., 352, 929-936, 1997.

Falkenmark, M., Berntell, A., Jägerskog, A., Lundqvist, J., Matz, M., and Tropp, H.: On the Verge of a New Water Scarcity: A Call for Good Governance and Human Ingenuity, Tech. rep., Stockholm International Water Institute Policy Brief, Stockholm International Water Institute, 2007.

Fiedler, K. and Döll, P.: Global modelling of continental water storage changes - sensitivity to different climate data sets, Adv. Geosci., 11, 63-68, doi:10.5194/adgeo-11-63-2007, 2007.

Flörke, M. and Alcamo, J.: European Outlook on Water Use: Final Report, Tech. rep., Center for Environmental Systems Research, University of Kassel, Germany, 2004.

Foster, S. and Loucks, D. P.: Non-Renewable Groundwater Resources: A guidebook on socially-sustainable management for water-policy makers, IHP-VI, Series on Groundwater No. 10, UNESCO, Paris, France, 2006.

Gleick, P. H., Cooley, H., Cohen, M. J., Morikawa, M., Morrison, J., and Palaniappan, M.: The Worlds Water 2008-2009, The Biennial Report on Freshwater Resources, Island Press, Washington, DC, USA, 2009.

Global Runoff Data Centre: Long-term mean monthly discharges and annual characteristics of GRDC stations, http://www.bafg.de (last access: 14 April 2011), 2008.

Guhathakurta, P. and Rajeevan, M.: Trends in the rainfall pattern over India, NCC Res. Report, 2, 1-23, 2006.

Haddeland, I., Skaugen, T., and Lettenmaier, D. P.: Anthropogenic impacts on continental surface water fluxes, Geophys. Res. Lett., 33, L08406, doi:10.1029/2006GL026047, 2006.

Hagemann, S. and Gates, L. D.: Improving a sub-grid runoff parameterization scheme for climate models by the use of high resolution data derived from satellite observations, Clim. Dynam. 21, 349-359, 2003.

Hanasaki, N., Kanae, S., and Oki, T.: A reservoir operation scheme for global river routing models, J. Hydrol., 327, 22-41, 2006.

Hanasaki, N., Kanae, S., Oki, T., Masuda, K., Motoya, K., Shirakawa, N., Shen, Y., and Tanaka, K.: An integrated model for the assessment of global water resources - Part 1: Model description and input meteorological forcing, Hydrol. Earth Syst. Sci., 12, 1007-1025, doi:10.5194/hess-12-1007-2008, 2008a.

Hanasaki, N., Kanae, S., Oki, T., Masuda, K., Motoya, K., Shirakawa, N., Shen, Y., and Tanaka, K.: An integrated model for the assessment of global water resources - Part 2: Applications and assessments, Hydrol. Earth Syst. Sci., 12, 1027-1037, doi:10.5194/hess-12-1027-2008, 2008b. 
Hanasaki, N., Inuzuka, T., Kanae, S., and Oki, T.: An estimation of global virtual water flow and sources of water withdrawal for major crops and livestock products using a global hydrological model, J. Hydrol., 384, 232-244, 2010.

Hoekstra, A. Y. and Hung, P. Q.: Globalisation of water resources: international virtual water flows in relation to crop trade, Global Environ. Change, 15, 45-56, 2005.

Islam, S., Oki, T., Kanae, S., Hanasaki, N., Agata, Y., and Yoshimura, K.: A grid-based assessment of global water scarcity including virtual water trading, Water Resour. Manage., 21, 1933, doi:10.1007/s11269-006-9038-y, 2007.

Joshi, U. R. and Rajeevan, M.: Trends in Precipitation Extremes over India, NCC Res. Report, 3, 1-25, 2006.

Klein Goldewijk, K. and van Drecht, G.: Integrated modelling of global environmental change: An overview of IMAGE 2.4, chap. HYDE 3: Current and historical population and land cover, MNP - Netherlands Environmental Assessment Agency, Bilthoven, The Netherlands, 93-112, 2006.

Knight, C. G., Raev, I., and Staneva, M. P.: Drought in Bulgaria: A Contemporary Analog for Climate Change, Ashgate Publishing, UK, 2004.

Koleva, E. and Alexandrov, V.: Drought in the Bulgarian low regions during the 20th Century, Theor. Appl. Climatol., 92, 113$120,2008$.

Komuscu, A.: An Analysis of Recent Drought Conditions in Turkey in Relation to Circulation Patterns, Drought Network News (1994-2001), Tech. rep., Drought - National Drought Mitigation Center, 2001.

Kummu, M., Ward, P. J., de Moel, H., and Varis, O.: Is physical water scarcity a new phenomenon? Global assessment of water shortage over the last two millennia, Environ. Res. Lett., 5, 034006, 2010.

Kundzewicz, Z. W., Mata, L. J., Arnell, N. W., Döll, P., Kabat, P., Jiménez, B., Miller, K. A., Oki, T., Sen, Z., and Shiklomanov, I. A.: Climate Change 2007: Impacts, Adaptation and Vulnerability. Contribution of Working Group II to the Fourth Assessment Report of the Intergovernmental Panel on Climate Change, chap. Freshwater resources and their management, Cambridge University Press, Cambridge, UK, 173-210, 2007.

Lehner, B. and Döll, P.: Development and validation of a global database of lakes, reservoirs and wetlands, J. Hydrol., 296, 1-22, 2004.

Liverman, D. M.: Drought: A Global Assessment, chap. 31: Adaptation to drought in Mexico, Routledge, New York, USA, 35-45, 2000.

Mihailescu, M., Mares, I., Mares, C., Hübener, H., and Cubasch, U.: Climate Variability of Drought Indices in Romania in the 20th and 21st Centuries, in: BALWOIS 2010: Water Observation and Information System for Balkan Countries, 25-29 May, Ohrid, Republic of Macedonia, 2010.

Ministry of Land, Infrastructure, and Transport in Japan: Water Resources in Japan (in Japanese), Ministry of Land, Infrastructure, and Transport in Japan, Tokyo, Japan, 2007.

Mishra, A. K. and Singh, V. P.: A review of drought concepts, J. Hydrol., 391, 202-216, 2010.

Mitchell, T. D. and Jones, P. D.: An improved method of constructing a database of monthly climate observations and associated high-resolution grids, Int. J. Climatol., 25, 693-712, doi:10.1002/joc.1181, 2005.
Naranjo-Diaz, L. and Pérez, P. C.: Cuba Country Case Study: Impacts and Responses to the 1997-98 El Niño Event, Tech. rep., University Corporation of Atmospheric Research, 2007.

Nathan, K. K.: Characteristics of Drought in Kerala, India, Drought Network News (1994-2001), Tech. rep., Drought - National Drought Mitigation Center, 2000.

New, M., Hulme, M., and Jones, P. D.: Representing twentieth century space-time climate variability, Part 2: development of 190196 monthly grids of terrestrial surface climate, J. Climate, 13, 2217-2238, 2000.

New, M., Lister, D., Hulme, M., and Makin, I.: A high-resolution data set of surface climate over global land areas, Clim. Res., 21, $1-25,2002$.

Oki, T. and Kanae, S.: Global hydrological cycles and world water resources, Science, 313, 1068-1072, doi:10.1126/science.1128845, 2006.

Oki, T., Agata, Y., Kanae, S., Saruhashi, T., Yang, D., and Musiake, K.: Global assessment of current water resources using total runoff-integrating pathways, Hydrolog. Sci. J., 46, 983-996, 2001.

Pokhrel, Y., Hanasaki, N., Koirala, S., Cho, J., Yeh, P. J. F., Kim, H., Kanae, S., and Oki, T.: Incorporating anthropogenic water regulation modules into a land surface model, J. Hydrometeorol., doi:10.1175/JHM-D-11-013.1, in press, 2011.

Portmann, F., Siebert, S., Bauer, C., and Döll, P.: MIRCA2000 Global monthly irrigated and rainfed crop areas around the year 2000: a new high-resolution data set for agricultural and hydrological modelling, Global Biogeochem. Cyc., 24, GB1011, doi:10.1029/2008GB003435, 2010.

Ramankutty, N., Evan, A. T., Monfreda, C., and Foley, J. A.: Farming the planet: 1. Geographic distribution of global agricultural lands in the year 2000, Global Biogeochem. Cy., 22, GB1003, doi:10.1029/2007GB002952, 2008.

Rohwer, J., Gerten, D., and Lucht, W.: Development of functional types of irrigation for improved global crop modelling, PIK Report 104, Tech. rep., Potsdam Institute for Climate Impact Research, Potsdam, Germany, 2007.

Rost, S., Gerten, D., Bondeau, A., Lucht, W., Rohwer, J., and Schaphoff, S.: Agricultural green and blue water consumption and its influence on the global water system, Water Resour. Res., 44, W09405, doi:10.1029/2007WR006331, 2008.

Sandu, I. and Mateescu, E.: Monitoring soil drought in Romania and the impact on agriculture, in: Inter-regional workshop on indices and yearly warning systems for drought, 8-11 December, Lincoln, Nebraska, USA, 2009.

Sheffield, J. and Wood, E. F.: Characteristics of global and regional drought, 1950-2000: Analysis of soil moisture data from off-line simulation of the terrestrial hydrologic cycle, J. Geophys. Res., 112, D17115, doi:10.1029/2006JD008288, 2007.

Shen, C., Wang, W. C., Hao, Z., and Gong, W.: Exceptional drought events over eastern China during the last five centuries, Clim. Change, 85, 453-471, 2007.

Shen, Y., Oki, T., Utsumi, N., Kanae, S., and Hanasaki, N.: Projection of future world water resources under SRES scenarios: water withdrawal, Hydrolog. Sci. J., 53, 11-33, 2008.

Shiklomanov, I. A.: Assessment of water resources and water availability in the world, Comprehensive assessment of the freshwater resources of the world, World Meteorological Organization and the Stockholm Environment Institute, 1997. 
Shiklomanov, I. A.: World Water Scenarios Analyses, chap. World water resources and water use: Present assessment and outlook for 2025, Earthscan, London, UK, 2000a.

Shiklomanov, I. A.: Appraisal and assessment of world water resources, Water Int., 25, 11-32, 2000b.

Siebert, S. and Döll, P.: Quantifying blue and green virtual water contents in global crop production as well as potential production losses without irrigation, J. Hydrol., 384, 198-217, 2010.

Siebert, S., Döll, P., Hoogeveen, J., Faures, J.-M., Frenken, K., and Feick, S.: Development and validation of the global map of irrigation areas, Hydrol. Earth Syst. Sci., 9, 535-547, doi:10.5194/hess-9-535-2005, 2005.

Siebert, S. D. P., Feick, S., Hoogeveen, J., and Frenken, K.: Global Map of Irrigation Areas Version 4.0.1., Tech. rep., Institute of Physical Geography, University of Frankfurt, Frankfurt am Main, Germany, 2007.

Simon, A. and Mohankumar, K.: Spatial variability and rainfall characteristics of Kerala, Proc. Indian Acad. Sci., 113, 211-221, 2004.

Smith, M.: CROPWAT - a computer program for irrigation planning and management, FAO Irrigation and Drainage Paper 46, FAO, Rome, Italy, 1992.

Stahle, D. W., Cook, E. R., Villanueva, D. J., Fye, F. K., Burnette, D. J., Griffin, R. D., Soto, R. A., Seager, R., and Richard, R. R.: Early 21st-Century Drought in Mexico, Eos, Trans. Am. Geophys. Union, 90, 89-90, 2009.

Steinfeld, H., Gerber, P., Wassenaar, T., Castel, V., Rosales, M., and de Haan, C.: Livestocks long shadow: Environmental issues and options, FAO, Rome, Italy, ISBN 978-92-5-105571-7, 2006.

Sulser, T., Ringler, C., Zhu, T., Msangi, S., Bryan, E., and Rosegrant, M. W.: Green and blue water accounting in the Ganges and Nile basins: implications for food and agricultural policy, J. Hydrol., 384, 276-291, 2010.

Suweis, S., Konar, M., Dalin, C., Hanasaki, N., Rinaldo, A., and Rodriguez-Iturbe, I.: Structure and controls of the global virtual water trade network, Geophys. Res. Lett., 38, L10403, doi:10.1029/2011GL046837, 2011.

Thenkabail, P. S., Biradar, C. M., Turral, H., Noojipady, P., Li, Y. J., Vithanage, J., Dheeravath, V., Velpuri, M., Schull, M., Cai, X. L., and Dutta, R.: An Irrigated Area Map of the World (1999) derived from Remote Sensing, Res., Rep., 105, Tech. rep., International Water Management Institute, Colombo, Sri Lanka, p.74, 2006.

Thenkabail, P. S., Biradar, C. M., Noojipady, P., Dheeravath, V., Li, Y. J., Velpuri, M., Reddy, G. P. O., Cai, X. L., Gumma, M., Turral, H., Vithanage, J., Schull, M., and Dutta, R.: A Global Irrigated Area Map (GIAM) Using Remote Sensing at the End of the Last Millennium, Tech. rep., International Water Management Institute, Colombo, Sri Lanka, p.63, 2008.

Türkes, M.: Meteorological Drought in Turkey: A Historical Perspective, 1930-93, Drought Network News (1994-2001), Tech. rep., Drought - National Drought Mitigation Center, 1996.

Tyagi, B. K., Hiriyan, J., Samuel, P., Tewari, S. C., and Paramasivan, R.: Dengue in Kerala: A Critical Review, ICMR Bulletin, 36, 13-22, 2006.

UNEP: Groundwater: A threatened resource, UNEP Environment Library No. 15, Tech. rep., UNEP, Nairobi, Kenya, p.36, 1996.
United States Department of Agriculture: Cubas Food \& Agriculture Situation Report, Tech. rep., United States Department of Agriculture, p.68, 2008.

Uppala, S. M., Kallberg, P. W., Simmons, A. J., Andrae, U., Bechtold, V. D. C., Fiorino, M., Gibson, J. K., Haseler, J., Hernandez, A., Kelly, G. A., Li, X., Onogi, K., Saarinen, S., Sokka, N., Allan, R. P., Andersson, E., Arpe, K., Balmaseda, M. A., Beljaars, A. C. M., Van De Berg, L., Bidlot, J., Bormann, N., Caires, S., Chevallier, F., Dethof, A., Dragosavac, M., Fisher, M., Fuentes, M., Hagemann, S., Holm, E., Hoskins, B. J., Isaksen, L., Janssen, P. A. E. M., Jenne, R., McNally, A. P., Mahfouf, J. F., Morcrette, J. J., Rayner, N. A., Saunders, R. W., Simon, P., Sterl, A., Trenberth, K. E., Untch, A., Vasiljevic, D., Viterbo, P., and Woollen, J.: The ERA-40 re-analysis, Q. J. Roy. Meteorol. Soc., 131, 2961-3012, 2005.

Van Beek, L. P. H. and Bierkens, M. F. P.: The Global Hydrological Model PCR-GLOBWB: Conceptualization, Parameterization and Verification, Report, Tech. rep., Department of Physical Geography, Utrecht University, Utrecht, The Netherlands, http: //vanbeek.geo.uu.nl/suppinfo/vanbeekbierkens2009.pdf/ (last access: 30 November 2011), 2009.

Van Beek, L. P. H., Wada, Y., and Bierkens, M. F. P.: Global monthly water stress: I. Water balance and water availability, Water Resour. Res., 47, W07517, doi:10.1029/2010WR009791, 2011.

Vörösmarty, C. J., Sharma, K. P., Fekete, B. M., Copeland, A. H., Holden, J., Marble, J., and Lough, J. A.: The storage and aging of continental runoff in large reservoir systems of the world, Ambio, 26, 210-219, 1997.

Vörösmarty, C. J., Green, P., Salisbury, J., and Lammers, R. B.: Global water resources: Vulnerability from climate change and population growth, Science, 289, 284-288, 2000.

Vörösmarty, C. J., Leveque, C., and Revenga, C.: Millennium Ecosystem Assessment Volume 1: Conditions and Trends, chap. 7: Freshwater ecosystems, Island Press, Washington DC, USA, 165-207, 2005.

Wada, Y., van Beek, L. P. H., van Kempen, C. M., Reckman, J. W. T. M., Vasak, S., and Bierkens, M. F. P.: Global depletion of groundwater resources, Geophys. Res. Lett., 37, L20402, doi:10.1029/2010GL044571, 2010.

Wada, Y., van Beek, L. P. H., and Bierkens, M. F. P.: Nonsustainable groundwater sustaining irrigation - a global assessment, Water Resour. Res., doi:10.1029/2011WR010562, in press, 2011a.

Wada, Y., van Beek, L. P. H., Viviroli, D., Dürr, H. H., Weingartner, R., and Bierkens, M. F. P.: Global monthly water stress: II. Water demand and severity of water, Water Resour. Res., 47, W07518, doi:10.1029/2010WR009792, 2011b.

Widén-Nilsson, E., Halldin, S., and Xu, C.: Global water-balance modelling with WASMOD-M: Parameter estimation and regionalization, J. Hydrol., 340, 105-118, 2007.

Wilhite, D. and Glantz, M. H.: Understanding the drought phenomenon: the role of definitions, Water Int., 10, 111-120, 1985.

Wint, G. R. W. and Robinson, T. P.: Gridded livestock of the world 2007, FAO, Rome, Italy, 2007. 
Wisser, D., Frolking, S., Douglas, E. M., Fekete, B. M., Vörösmarty, C. J., and Schumann, A. H.: Global irrigation water demand: Variability and uncertainties arising from agricultural and climate data sets, Geophys. Res. Lett., 35, L24408, doi:10.1029/2008GL035296, 2008.

Wisser, D., Fekete, B. M., Vörósmarty, C. J., and Schumann, A. H.: Reconstructing 20th century global hydrography: a contribution to the Global Terrestrial Network- Hydrology (GTN-H), Hydrol. Earth Syst. Sci., 14, 1-24, doi:10.5194/hess-14-1-2010, 2010.

World Resources Institute: World Resources: A Guide to the Global Environment 1998-99, World Resources Institute, Washington DC, USA, 1998.

World Water Assessment Programme: Water for people: Water for life, The United Nations World Water Development Report, UNESCO, Paris, France, 2003.
World Water Assessment Programme: Water in a Changing World, The United Nations World Water Development Report 3, UNESCO, Paris, France, 2009.

Yeh, P. J. F. and Famiglietti, J. S.: Regional groundwater evapotranspiration in Illinois, J. Hydrometeorol., 10, 464-478, doi:10.1175/2008JHM1018.1, 2009.

Yildiz, O.: Assessing temporal and spatial characteristics of droughts in the Hirfanli dam basin, Turkey, Sci. Res. Essay, 4, 249-255, 2009.

Zavoianu, I.: Romania's Water Resources and Their Use, GeoJournal, 29, 19-30, 1993.

Zhuguo, M. A., Li, D. N., and Yuewen, H. U.: The extreme dry/wet events in northern China during recent 100 years, J. Geogr. Sci., 14, 275-281, 2004. 